\title{
Determination Methods for the Exoskeletal Remains of Early Vertebrates ${ }^{1}$
}

\author{
Valentina Karatajute-Talimaa ${ }^{2}$
}

With 25 Figures

\begin{abstract}
The exoskeleton, consisting of micromeric elements (odontodes) and their derivatives, is characteristic of the most ancient vertebrates. Great morphological and histological variability of discrete exoskeletal microremains makes it difficult to identify them. It is necessary to study not only separate scales or tesserae, but also to get a picture of the squamation in general, because species determined from discrete elements are understood as an assemblage of morphological types. For determination of discrete exoskeletal elements, their morphology, internal structure, defined tissue types of crown and basal plate, types (way) of their growth, system of vascular canals should be studied in addition changes occuring during ontogenetic development of both the dermal skeletal elements and the squamation should be taken in consideration. The material of different groups of early vertebrates (astraspids, tesakoviaspids, heterostracans, thelodonts, mongolepids, chondrichthyans and acanthodians), which were widely distributed in the Early Palaeozoic, are used as examples.
\end{abstract}

Key words: Early vertebrates, exoskeleton, micromeric elements, types of growth, ontogenetic development, squamation.

\section{Zusammenfassung}

Ein Hautskelett aus mikromerischen Elementen (Odontodes) und davon abgeleiteten Formen ist für die meisten frühen Vertebraten kennzeichnend. Große morphologische und histologische Variabilität der einzelnen Mikroreste des Hautskeletts bereitet bei ihrer Bestimmung Schwierigkeiten. Es ist notwendig, nicht nur isolierte Schuppen und Tesserae zu untersuchen, sondern man muß sich eine Vorstellung der gesamten Beschuppung verschaffen, da Arten bestimmt auf isoliertem Material als eine Ansammlung von morphologischen Typen verstanden werden müssen. Bei der Bestimmung isolierter Elemente des Außenskeletts sollte man deren Morphologie, innere Struktur, Gewebetypen der Krone und Basalplatte, Arten des Wachstums, Anordnung der Gefäßkanäle und Veränderungen während des Wachstums des Einzelelements und der Gesamtbeschuppung berücksichtigen. Hautskelett-Elemente der verschiedenen Gruppen früher Vertebraten (Astraspiden, Tesakoviaspiden, Heterostraken, Thelodontier, Mongolepiden, Chondrichthyer und Acanthodier), die im frühen Paläozoikum weit verbreitet sind, werden als Beispiele benutzt.

Schlüsselwörter: Frühe Vertebraten, Exoskelett, mikromere Elemente, Wachstumstypen, Ontogenese, Beschuppung.

\section{Introduction}

The significance of vertebrate remains for the subdivision and correlation of heterofacial sedimentary deposits has been increasingly recognised world-wide. By application of chemical methods to extract phosphatic remnants, exoskeletal parts of vertebrates are found in rocks of different lithological composition, so that a huge database has been accumulated world-wide. Extremely diverse microremains (also known as ichthyoliths and microvertebrates) of different fishes are found together with macroremains. Samples may contain bones, teeth, fin spines, scales and tesserae of different ontogenetic stages from a large number of the species buried in the same bed. Determination of such an amount of material, complicated by its varied taxonomic composition, is fraught with a number of difficulties principally of a methodical nature.

At present the following two main methods exist to treat a mass of phosphatic micromaterial:

1. Striving for natural systematisation, for a binominal nomenclature to determine fossil ichthyoliths: An artificial classification is created for discrete micromaterial. This is inevitable until articulated specimens of the animals are found. Hence, the great importance

\footnotetext{
1 Contribution to IGCP 328: Palaeozoic Microvertebrates and IGCP 406: Circum Arctic Palaeozoic Vertebrates.

2 Institute of Geology, T. Đevèenkos str. 13, LT 2600 Vilnius, Lithuania. Received January 1998, accepted July 1998
} 
of the search for, and thorough study of intact specimens of agnathans and jawed fishes, which results not only in knowledge of their general morphology, but also in knowledge of the dentition, squamation, microstructure of scales of different morphological varieties and different ontogenetic, or growth stages.

2. Utilitarian trend-coding of morphological features and creation of a numerical descriptor system: Such a description code can be manipulated by computers to give biostratigraphical data. This method was worked out using ichthyoliths from Tertiary and Mesozoic pelagic deposits, which rarely contain other useful fossils (Doyle \& Riedel 1979), and later was applied to Late Carboniferous ichthyoliths from a great number of beds in North America (Tway 1979, 1984, Tway \& Zidek 1982, 1983a, b). According to these authors, the system of utilitarian classification considerably facilitates the use of ichthyoliths for stratigraphical purposes and the solution of palaeoecological problems.

What is the best practical solution for our purposes? In my opinion, it is more expedient to study micromaterial using the first method. Since, equal to the practical task of a determining stratigraphical character, a solution to the following theoretical problems is necessary: the sequence of ontogenetic development of the exoskeleton, total number of palaeontological species, establishment of higher rank taxa, interrelationships at different taxonomic levels, systematics of the separate vertebrate groups, and their apparent phylogenetic development. It is also necessary to reach high resolution of the stratigraphy. For detailed biostratigraphy and the creation of zones, phylogenetic principles should be used.

In this article I attempt to give an account of the principal methodological state, where species determined from discrete material are understood as an assemblage of morphological types. I will use examples of scales and tesserae of fish exoskeletons (squamation) from the following lower vertebrates: astraspids, tesakoviaspids, heterostracans, thelodonts, mongolepids, chondrichthyans and acanthodians.

To determine species (also for taxonomic units of higher rank) known only from separate dermal elements, it is necessary to study:

a) Separate scales or tesserae. 1. General morphological characters, 2. internal composition (histology), 3. types of crown and basal plate tissues, 4. mode of crown and basal plate growth, 5. growth type of whole scale and tessera, 6. system of vascular tubules or canals, 7 . ontogenetic sequence of development of dermal skeletal elements (from initiation between epidermis and mesoderm up to their maturity, or shedding).

b) Squamation. 1. Determination of morphology of all possible variants of scales, including those from head to tail and fins, 2. determination of growth type of the scale cover, 3 . ontogeny of squamation, 4. relationship of scales to each other (such as, degree of overlap and special joints) and the form of attachment to the dermis, 5. determination of any pathological states.

Before starting an examination of more concrete examples, it is necessary to consider the principal terms, which have been used earlier by those palaeontologists who built the theoretical basis of our knowledge on the origin and growth of exoskeleton elements. The main workers are Tor Ørvig, Erik Stensiö (Stockholm), Walter Gross (Berlin, Tübingen), and Wolf-Ernst Reif (Tübingen).

The lepidomorial theory was proposed on the basis of discrete scales of Late Permian edestides (elasmobranchs) by Ørvig and Stensiö (Stensiö \& Ørvig 1951, Ørvig 1951, Stensiö 1961, 1962). The odontode theory (Ørvig 1967, 1968, 1977), which later won wide recognition, was a continuation of investigations of the theoretical basis of elaboration of the formation of exoskeleton. The theory of odontode regulation proposed by Reif (Reif 1982 a, b) was a subsequent development of Ørvig's odontode theory. Later works have been published, where new or exchanged terms were used, not infrequently, synonyms of already known ones, thus creating confusion and leading to redundant alternatives. First I define the terms used in this review.

\section{Glossary}

Lepidomorium (lepidomoria - Ørvig 1951: 366, Stensiö 1961: 241, 1962): “The simple scale units, the smallest of the exoskeleton. The individual lepidomorium consists of an enamel-coated crown of dentine and basal plate of bone situated in the corium. To judge from the two canals leading out from its pulp cavity each lepidomorium arose ontogenetically from a simple corium papilla formed around a single vascular loop 


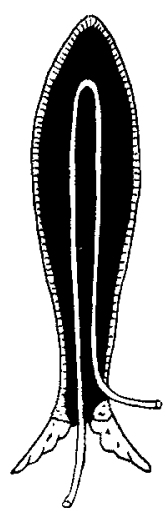

A

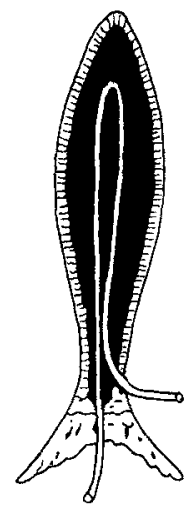

B

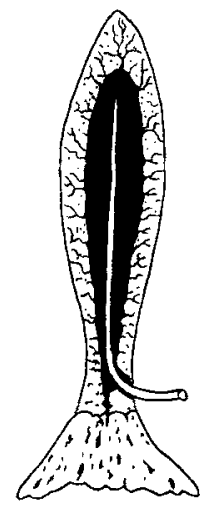

c

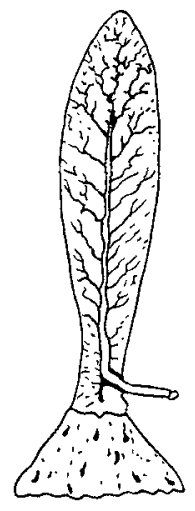

D
Fig. 1. A-D, ontogenetic development of lepidomorium (after Stensiö 1962, pl. II, D $3-6$ )

which ascended in a superficial direction from the sub-epidermal vascular plexus of the corium" (Stensiö 1961: 241) (Fig. 1).

Cyclomorial scales (Gross 1938: 135-144, Ørvig 1951: 367, Stensiö 1961, 1962) - growing scales (Reif 1978): “... scales which grew in areas by marginal apposition of consecutive areal zones around a primordium ... possess a bony basal plate of a laminate structure ..." (Ørvig 1951: 367, Stensiö 196: 237).

Stiphronal cyclomorial scales: “... component crowns of each areal zone are in a rigid contact (basally or throughout their depth) with the earlier-formed portion of the compound scale crown" (Stensiö 1961: 244) (Figs 2, 3).

Churtonal (Adesmic, Ørvig 1951: 390, fig. 14A) cyclomorial scales (Fig. 4): "Characterized by the conditions that the crowns of their component scales all lie some distance apart throughout their depth and therefore appear as scattered tubercles or cusps on the bony cyclomorial basal plate" (Stensiö 1961: 244).

Synchronomorial (Ørvig 1951: 367, Stensiö 1961: 237) monodesmic (Ørvig 1951: 390, 391) nongrowing (Reif 1978) scales (Fig. 5): “... Young synchronomorial ("placoid") scales contain only a single, wide pulp cavity which represents the pulp cavities of the original primordium and of all original zonal component scales". "... this complex pulp cavity was gradually subdivided into minor secondary pulp cavities which correspond to the pulp cavities of the original simple or complex component scales ...". "... minor pulp cavities are all in communication with each other by numerous vascular canals throughout their depth". "... crown portion became surrounded by a continous, complex enamel organ, which gave rise to a single, continous enamel layer ...". The basal plate lacks all traces of lamination and is always of uniformly thin, dish-like shape (Stensiö 1961: 243).

Placoid scales have been interpreted as primitive scale formations since Hertwig's time (Hertwig 1874a, 1876, 1879). Commonly, the term has been used for microsquamous (micromeric) scales of Recent elsmobranchs and holocephalans. However, very often scales of thelodonts are also included as placoid scales or "dermal teeth" (denticles).

According to Stensiö's determination "placoid" scales are synchronomorial scales "at a very advanced stage of specialisation" (Stensiö

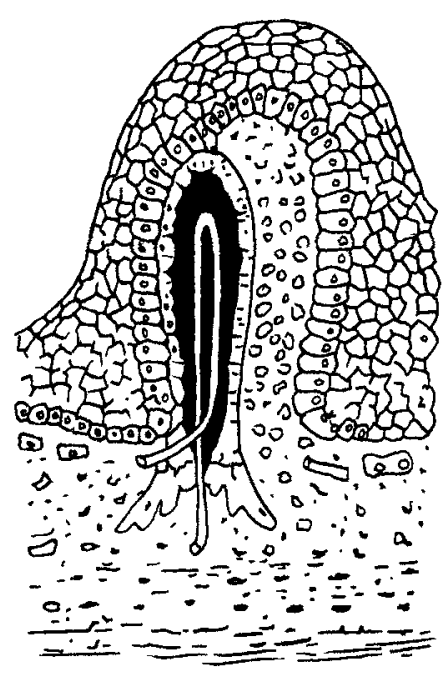

A

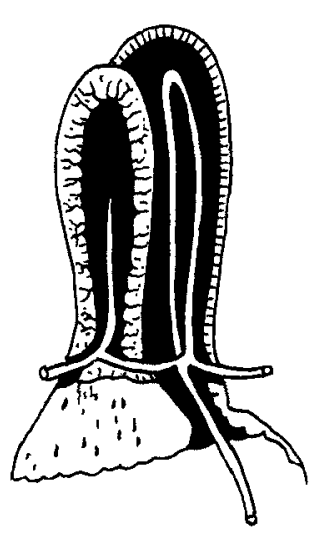

B

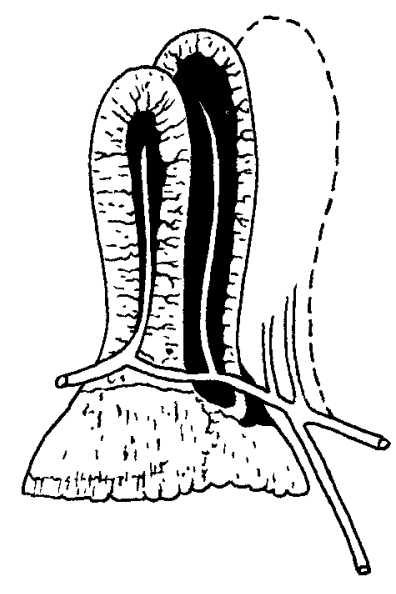

C

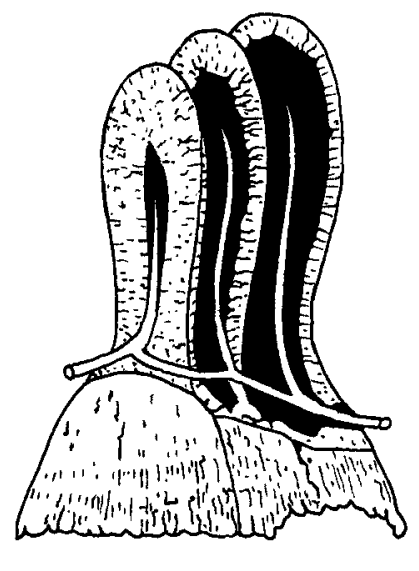

D

Fig. 2. A-D, four stages in the ontogenetic development of a tri-lepidomorial, stiphronal cyclomorial scale which grows in area on one side only. Progressing growth in depth of the basal plate and formation of the laminate structure of the basal plate (after Stensiö 1962, pl. II, fig. $F_{2,4,5,8}$ ) 


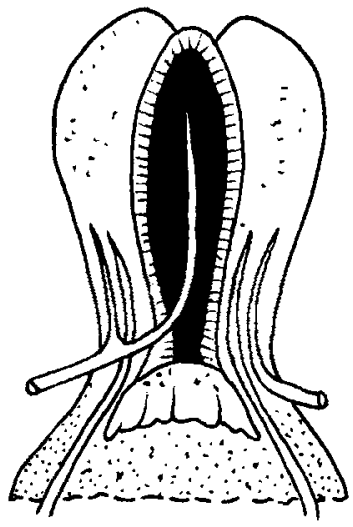

A

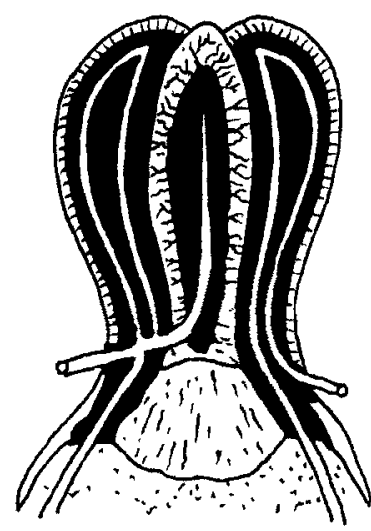

B
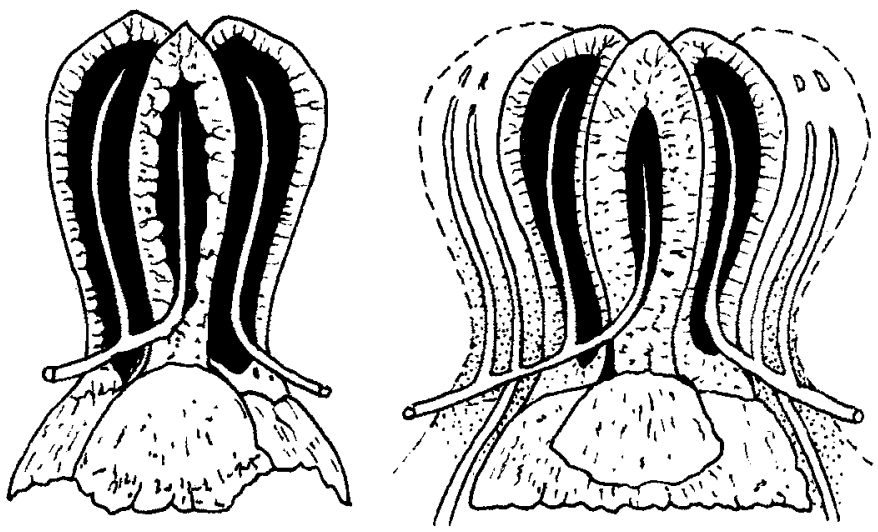

C

D

Fig. 3. A-D, four stages in the ontogenetic development of a penta-lepidomorial stiphronal cyclomorial scale which grew on two opposite sides and possessed two areal zones, each of which consisted of two lepidomoria (after Stensiö 1962, pl. II, fig. $\mathrm{G}_{1,3,5,7)}$
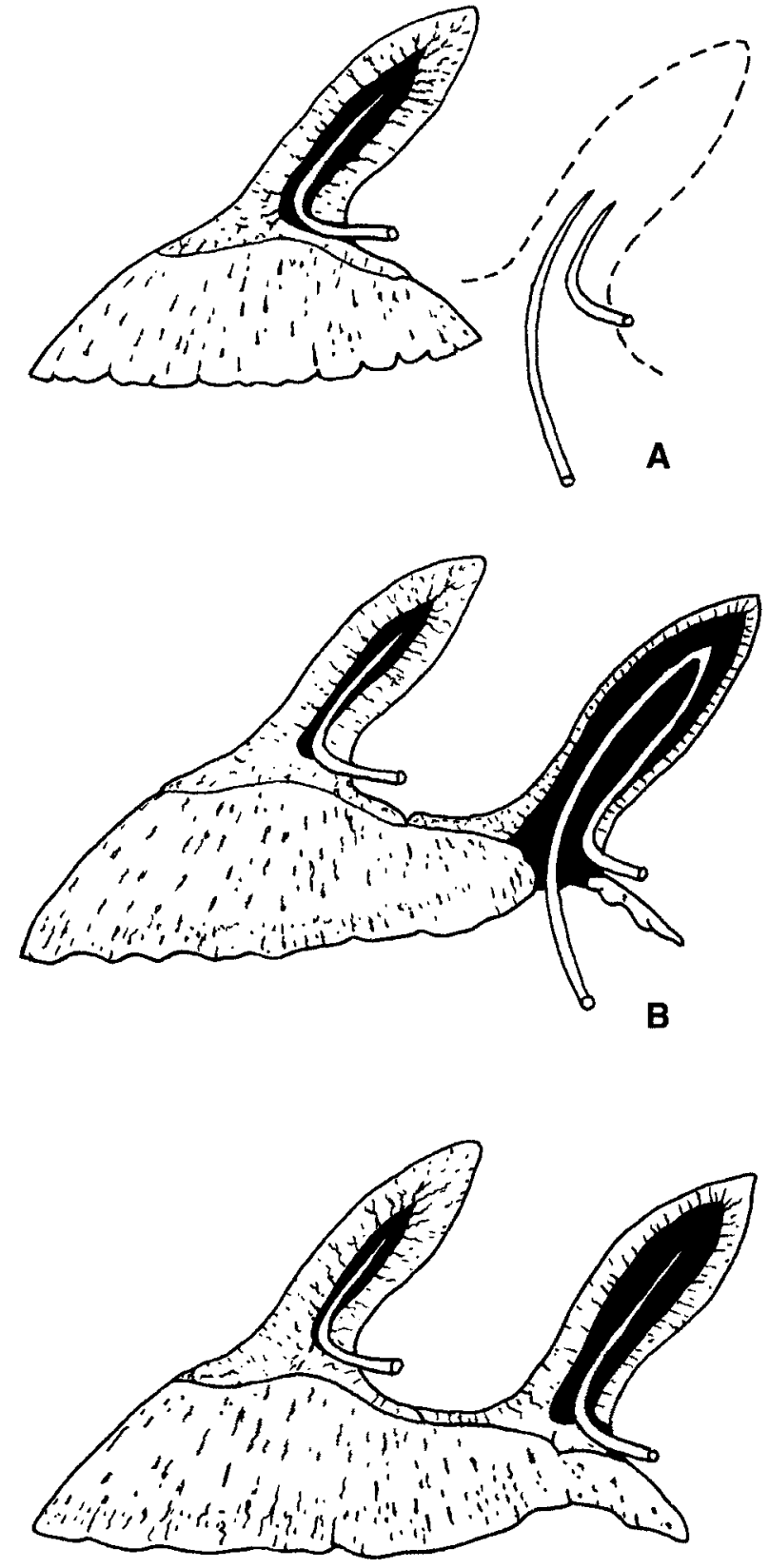

C
1961: 237). Consequently, a placoid scale of Recent elasmobranchs is a complex formation and corresponds to the "... compound stiphronal synchronomorial scale" (Stensiö 1961: fig. 2, $\mathrm{O}_{1-13}$ ) (see Fig. 5).

Stensiö (1961: 233) has given the following description of placoid scales:

“... simple dermal tubercles or dermal teeth in which one can distinguish a more or less high crown and basal plate separated from each other by narrow neck portion. The crown consists of dentine coated superficially with a layer of enamel-like hard tissue, at their young stages the placoid scales contain a large pulp cavity which opens downwards on the basal face of the basal plate through a wide basal canal and by 3 to 15 or more neck-canals, the neck-canals, or isthmic canals of Williamson, which perforate the neck portion".

Zangerl (1981: 1) summarised Stensiö's description ". . . the placoid scales of modern sharks are "synchronomoria", the product of simultaneous fusion of a group of lepidomoria". Stensiö assumed that the "synchronomorial" fusion takes place at the papillary stage of development.

Differences in the structure of thelodont scales and "placoid" scales of chondrichthyans consist mainly in the presence of neck canals

Fig. 4. $\mathbf{A}-\mathbf{C}$, ontogenetic development of a di-lepidomorial churtonal cyclomorial scale which grew on one side only (after Stensiö 1962, pl.II, fig. $E_{2-4}$ ) 


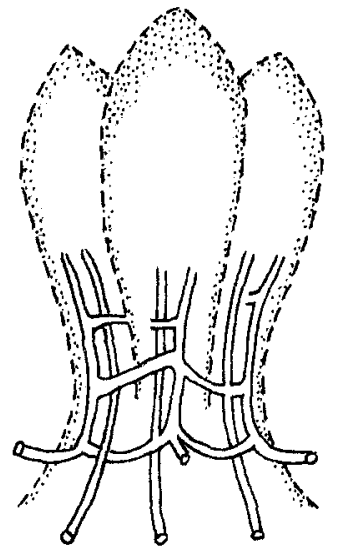

A

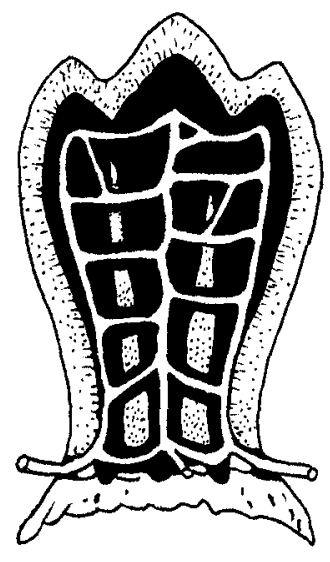

D

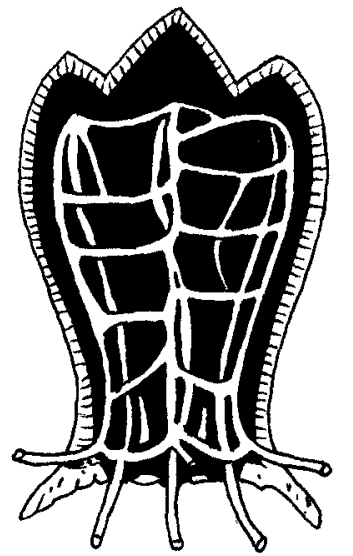

B

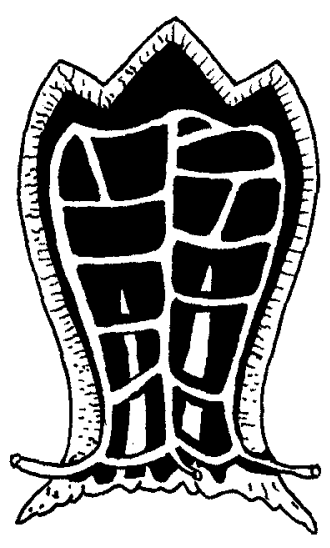

C

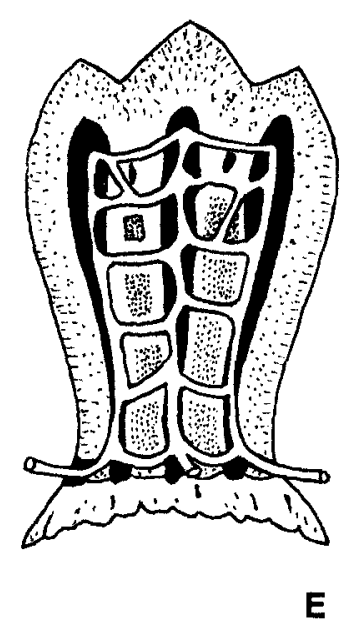

E

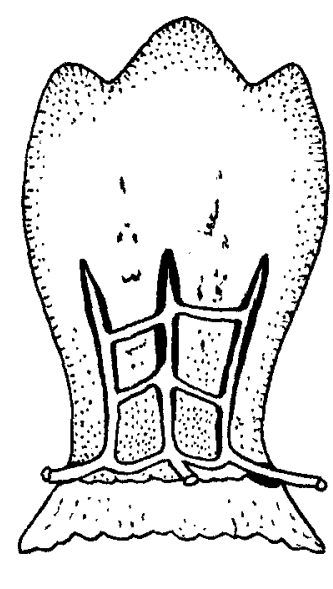

F
Fig. 5. A-F, five successional stages in the ontogenetic development of the hard tissues of the simple stiphronal synchronomorial scale ("placoid" scale). Large compound synchronomorial pulp cavity gradually subdivided into secondary lepodomorial pulp cavities by the increase in thickness inwards of the dentine (after Stensiö 1962, pl. II, fig. $\mathrm{O}_{3}, 5,7,9,11,12$ )

and a complex pulp cavity in scales of the latter. Consequently, the term "placoid scale" should not be used in the case of thelodont scales. Among Early Palaeozoic chondrichthyans, the scales of Elegestolepis, which have one neck and one basal canal developed, could be an example of simple "placoid" scales (Karatajute-Talimaa 1973, Novitskaya \& Karatajute-Talimaa 1986, Karatajute-Talimaa \& Predtechenskyj 1995). An example of complex synchronomoria are Polymerolepis scales (Karatajute-Talimaa 1977).

I should explain at greater length my point of view on the origin and structure of exoskeletal elements of synchronomorial type and placoid scales because opposite viewpoints on this problem exist. Janvier (1996: 278) adduced definition of "lepidomorial theory" (Stensiö 1962) and "odontode regulation theory" (Reif 1982) and fairly mentioned that the authors of these theories understood origin of synchronomorial nongrowing placoid scales in different ways. Reif did not accept evidence of fusion of odontodes at

the papillary level. Among pictures explaining non-growing odontodes (scales in the exoskeleton) Reif represented two: appearance in the skin of simple non-growing odontodes and morphogenetic mechanism in which a small scale is replaced by a large scale (Reif 1982b, figs 4, 5). Reif did not discuss placoid scales with a complex pulp cavity and a single, continous dentine layer in the crown.

In my opinion, the structure of Polymerolepis whitei Karatajute-Talimaa scales serves as a good example of a synchronomorial scale containing a complex pulp cavity. This confirms Stensiö's hypothesis on the possible junction of odontodes at their papillar stage of development (Fig. 5).

In Figure 6 the morphological set of scales of Polymerolepis whitei (Karatajute-Talimaa 1977: fig. 3), which illustrate morphological diversity of scales in different regions of the body, is presented. A large complex crown, a thin basal plate around a large open basal depression, a great number of basal pulp openings and a num- 

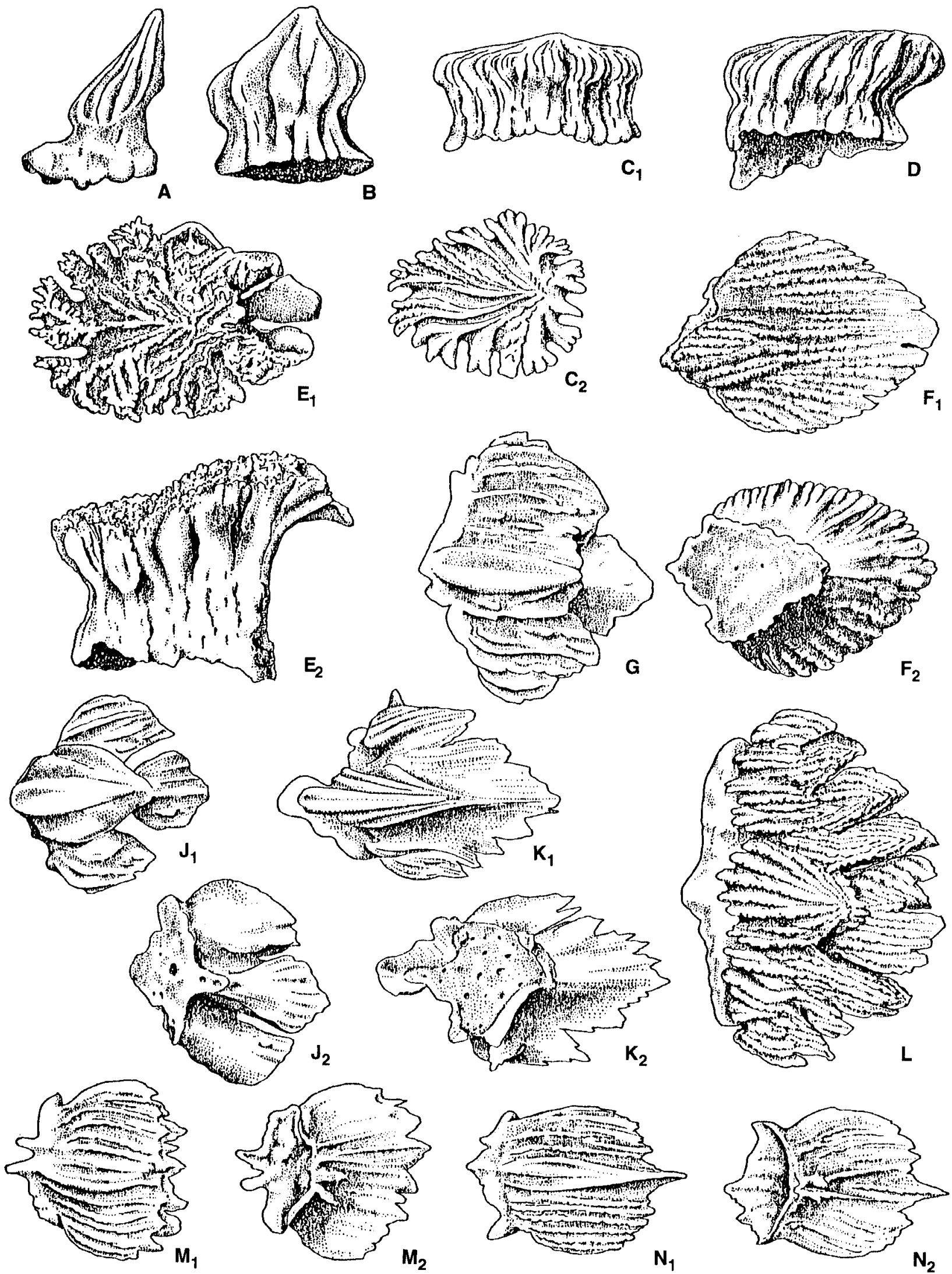

$1 \mathrm{~mm}$

Fig. 6. Polymerolepis whitei Karatajute-Talimaa. Morphological varieties of scales (after Karatajute-Talimaa 1977, fig. 3). $\mathbf{A}-\mathbf{E}$, head scales; $\mathbf{F}-\mathbf{L}$, body scales; $\mathbf{M}-\mathbf{N}$, body (tail) scales 
ber of neck canals openings (Fig. 7) are characteristic of scales of Polymerolepis type. The internal structure of the scales (Fig. 8) is typical of complex synchronomoria. The large complex pulp cavity is subdivided by partitions into smaller ones. A complete dentine layer covers the crown on the outside.
Odontode: The unit odontode that develops from an interactive morphogenic system was elaborated by Schaeffer (1977). The term was first proposed by Ørvig (1967). An odontode is formed ontogenetically from a single, undivided dental papilla of mesenchymal soft tissue limited by an epithelial dental organ of the adjoining

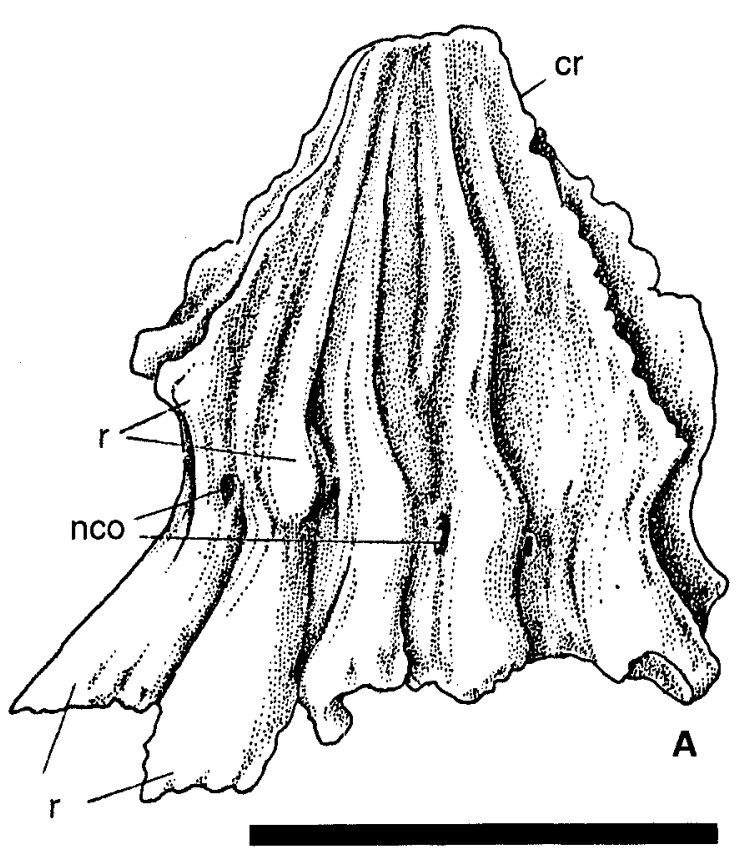

$0,5 \mathrm{~mm}$

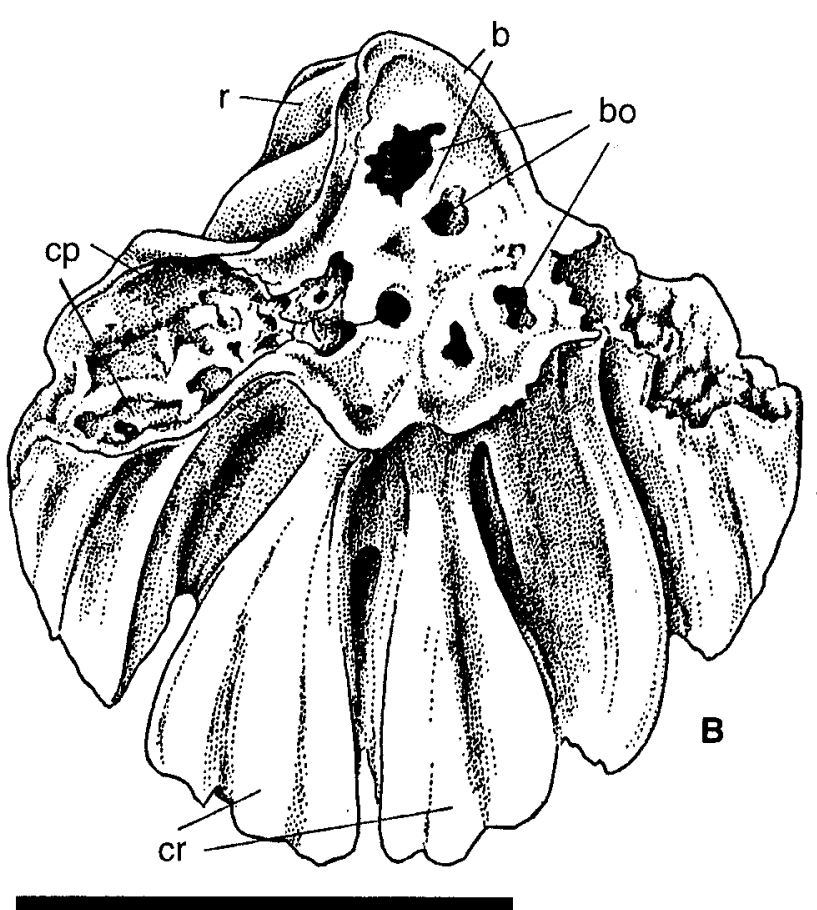

$0,5 \mathrm{~mm}$

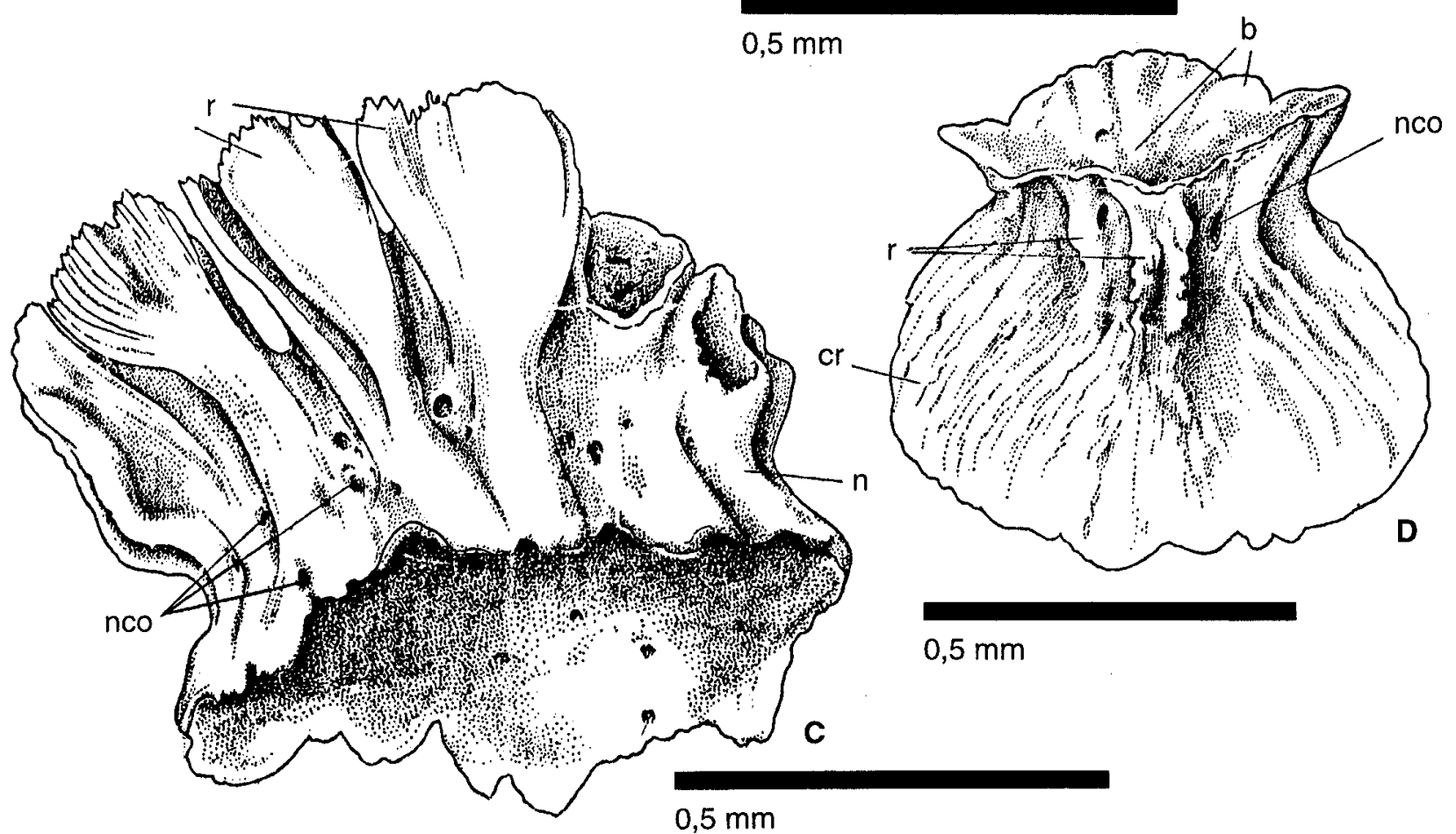

Fig. 7. Polymerolepis whitei Karatajute-Talimaa. A, head scale, lateral view; B-C, body scales, view from below; D, leaf like body (tail) scale, view from below;

b - base; bo - opening in the basal lamina; $\mathbf{c p}$ - complex pulp cavity; cr - crown; $\mathbf{n}$ - neck; nco - neck canal opening; $\mathbf{r}$ ridge of crown (after Karatajute-Talimaa 1977, fig. 2) 
epidermis. An odontode consists of dentine or of some kind of dentinous tissue; it frequently possesses a superficial enameloid layer, and does not belong to the dentition sensu stricto (Ørvig 1977: 54). An odontode is an isolated superficial structure of the dermal skeleton. A hypermineralized cap of enameloid can be present (Reif 1982b: 290). However, Reif distinguished two kinds of odontodes - dermal denticles and teeth. He also included basal bone as part of the
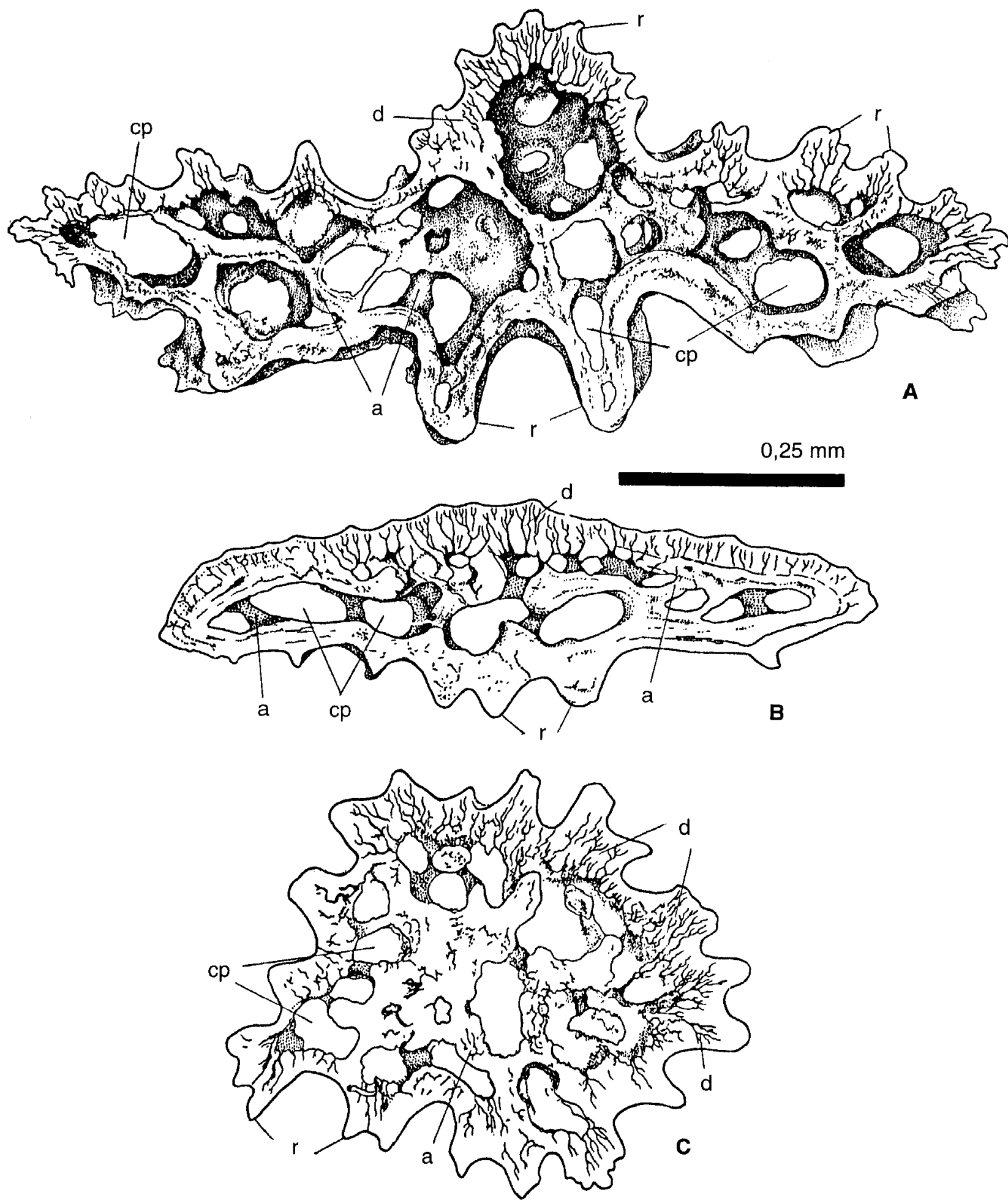

Fig. 8. Polymerolepis whitei Karatajute-Talimala. A, vertical cross section of body scale; B, vertical cross section of body (tail) scale; $\mathbf{C}$, horizontal section of head scale;

$\mathbf{a}$ - partitions between the sccondary pulp cavities; $\mathbf{c p}$ - complex pulp cavity; $\mathbf{d}$ - dentine; $\mathbf{r}$ - ridge of crown (after Karatajute-Talimaa 1977 , fig. 65,2 ; fig. $5_{2}$ ) 
odontode, as Stensiö had originally proposed. In the concept of Smith and Hall (1990, 1993) odontodes are products of a morphogenetic unit (the odontode primordium) developing through epitheliomesenchymal cooperative interactions. Janvier (1996: 278) defines odontode as a dentinous element, possibly covered with enamel or enameloid, which forms from a single dermal papilla.

Odontodium: A scale which consists of an odontode situated on a small bony basal plate, or a group of odontodes on such a plate (Ørvig 1977: 55). Ørvig considered the basal plate as separate from the odontode.

Monodontodium: Scale when the crown is made up of one odontode only, like those of thelodonts and many selachians (Ørvig 1977: 55).

Polyodontodium: Crown of scale which contains a number of separate odontodes (like those of the early selachian Ohiolepis, Ørvig 1977: 55). Such scales can be of growing type (Ohiolepis, Protacrodus) or non-growing type (mongolepids, Lugalepis).

Odontocomplexes: One type of growing polyodontodium, where columns or clusters of odontodes during consecutive growth stages have developed directly upon or beside each other (Ørvig 1977: 54).

"Odontocomplexes". The structure developed in scales with non-growing crown in various genera of mongolepids. The odontodes are disposed in longitudinal rows (Karatajute-Talimaa 1992, 1995, Karatajute-Talimaa \& Novitskaya 1997).

The exoskeletal elements (scales, tesserae, plates) were subdivided by Gross (1966) according to their size:

1. "Kleinschuppen" in size of 0.2 (or less) to $3.0 \mathrm{~mm}$ (Thelodontida, Acanthodii, "Selachii", Actinopterygii: genus Cheirolepis),

2. "Großschuppen" (Heterostraci, Cephalaspida, Anaspida, Placodermi and all Teleostomi with the exception of Cheirolepis).

Ørvig (1968: 381) introduced the terms: micromeric, mesomeric, macromeric to identify the size of exoskeletal parts. In the skeletal assimilation process, Ørvig distinguished an initial naked stage, a primary micromeric stage in which the dermal skeleton consists throughout of minute, evenly distributed scales, a primary mesomeric stage in which plates and scales of larger size emerge, and a macromeric stage in which the mesomeric elements provide building material for a system of dermal bones or a continous der- mal armour. In contrast, in the regressive phase, the dermal skeleton develops from a macromeric stage into a secondary mesomeric stage, secondary micromeric and a secondary naked stage.

Correspondingly, Ørvig used the terms micromeric dermal elements, mesomeric and macromeric dermal elements, micromeric and mesomeric squamation and macromeric shield.

Reif (1982b), later proposed the terms $\mathrm{mi}$ crosquamose, mesosquamose and macrosquamose.

In 1964 Stensiö proposed the term "areal zones of growth" ("zones areales proprement dites", Stensiö 1964: 173-179), which Ørvig recoined "superpositional growth" and combined "areosuperpositional growth" (Ørvig 1968: 389).

Structure and ontogenetic development of exoskeletal (dermal) micromeric elements

An exoskeleton of small $(0.1-3.5 \mathrm{~mm})$ elements (scales, tesserae or plates) is characteristic for many Palaeozoic lower vertebrates. The scales and tesserae can be "monodontodia", where the crown consists of one odontode, or "polyodontodia", where crowns are built by odontodes of different types and different mode of growth.

Every description of dermal skeletal elements should give the following characteristics:

Morphological characteristics:

1. Size and form of the element (or elements) should be described separately for crown and basal plate, with special attention to the symmetry of the elements. It is advisable to indicate left and right scales if they are asymmetrical (Fig. 9).

2. Proportions and shape of crown and basal plate, the relationship to each other in size, form of any overlapping area on the periph-
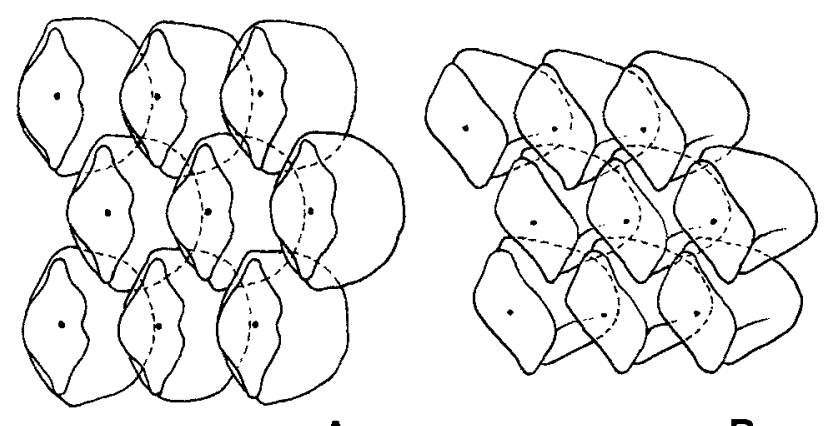

A

B

Fig. 9. Elegestolepis grossi Karatajute-Talimaa. A, arrangement of symmetrical (dorsal and ventral) scales in the skin, from inside; $\mathbf{B}$, arrangement of asymmetrical scales (scales of the right side of the body) in the skin, from inside (after Karatajute-Talimaa 1977, fig. 5 N, O) 
ery or on the anterior and overlaid areas of the posterior section, contours of the edge of the crown, particularly of the posterior part.

3. Presence or absence of a "neck" (zone between crown and basal plate), its shape, height, size, and nature of the interface between crown and base.

4. Presence or absence of sculptural elements on crown and neck, their shape and extent.

5. Style of the sculpture on dorsal and ventral surfaces of the crown.

6. Presence or absence of microornament or microsculpture (normally only seen in SEM and in well preserved specimens).

7. Presence or absence of a pulp cavity or pulp/ dental canal cavities in the base, their shape, depth and extent.

8. Presence or absence of pulp aperture or apertures, their disposition on basal plate and neck.

9. Presence or absence of apertures of vascular canals on basal plate and neck, their amount and shape.

10. Presence, disposition and shape of sensory pore canals in lateral line elements and related changes of shape.

11. Colour and texture of microremains, degree and style of preservation and suitability for histological examination.

12. Any diagenetic or pathological indications, wear facets, fungal/algal attacks etc.

Histological characteristics:

By examination of the internal structure of exoskeletal elements, various types of hard tissue can be determined. Crown, neck and basal plate can be formed of different tissues. These, the presence, shape and extent of cavities, and also any system of vascular canals must be determined. Varieties of enamel, enameloid, dentinal and bony tissues must be determined in the crown and basal plate. Correspondingly, those tissues of mesomeric tesserae and macromeric plates which form the external sculptured layer, and tissues of the middle and basal laminae should be determined.

For the determination of hypermineralized tissues (enamel and enameloid) it is necessary to study them at ultrastructural level to determine organization of the apatite crystals (Moss 1970, Reif 1973a). At low magnification under compound microscope the layer of enameloid tissue is characterised by absence of canalicules, absence of lamination, high transparency and hardness. For correct identification of hyperminera- lized tissues, it is necessary to understand their histogenesis. Most clearly this process is discussed in the Smith's work (1995: 134-140, figs 7.4-7.6).

For the identification of dentinal tissue types, thin sections can be used, or examination in anise or other clear heavy organic oil (e.g. eucalyptus) may be sufficient. The second method is applied for comparatively thin structures, which are not too dark are not substituted by pyrite or other iron components; Karatajute-Talimaa (1978) and Karatajute-Talimaa \& Predtechenskyj (1995) described this method. Care must be taken to wash specimens in alcohol after application of the oil, or the scale will be ruined. Structure of dentinal tissues can be drawn but is best studied applying both methods. From this it is necessary to determine:

1. Presence or absence of dentine tubules in odontodes.

2. Shape, length, thickness and extent of dentine canals and/or tubules, and their branching mode.

3. The phase where the apertures of dentine canals and/or tubules open.

4. Presence or absence of lamination (incremental lines of thin layers of growth).

5. Presence or absence of canals or tubules joining lacunae.

6. Presence, amount, shape and extent of pulp canals and pulp cavities, their size in elements of different stages of their ontogenetic development.

7. Presence and disposition of vascular canals. As far as possible, it is necessary to produce the reconstruction of the whole system of canals and any alteration during the process of ontogenetic development of each element.

It is also necessary to study the internal bony tissue of the basal plate or middle and basal laminae of tesserae and plates:

1. Presence or absence of bone cells, their shape and character of the processes.

2. Presence of fine canals for intrinsic fibre bundles in aspidine.

3. Presence and disposition of canals (tubules) of Sharpey's fibres.

4. Thickness of (bony) laminae of non-growing scales, which is reached during their ontogenetic development.

5. Presence of growth lines of the first and second orders and their thickness.

6. Presence, origin and shape of vascular (ascending) canals. 
7. During examination of the middle and basal laminae, the size and shape of osteons and aspidons. Thickness of interstitial regions ought to be constant in tesserae and plates.

The three following stages of ontogenetic development of an individual exoskeletal element can be distinguished: I - initial, II - early, III late. Each stage can be determined:

a) In scales containing a non-growing crown and growing basal plate by the size of pulp cavities and pulp canals, by the size of the basal plate, its extent, and by the size of the basal aperture or by the degree of secondary and horizontal canal formation. Examples are the ontogenetic development of scales (monodontodium) of thelodonts and chondrichthyans of Elegestolepis type (Fig. 10), and of polyodontodium, scales of mongolepidids, containing a complex synchronomorial crown (Fig. 11).

b) In growing elements of the dermal skeleton by the number of odontodes or of superpositional or areal growth zones in the crown and by the number of growth laminae in the basal plate. Examples are the ontogenetic development of chondrichthyan scales of Protacrodus type (Fig. 12), acanthodian scales, and Tesakoviaspis and Astraspis tesserae.

Four principal stages of development of exoskeletal elements, the crown of which is laid down simultaneously and does not grow, can be distinguished:
Stage I "papillar": Formation of the element (scale) in the corium at the boundary between mesoderm and epidermis. Only a simple or complex cap of the crown is present (see Text-fig. 10). Its size remains invariable during the whole period of the scale's existence. Only pulp cavities of odontodes are distinguished on the lower surface of the crown. A basal plate is absent. Pulp cavities of odontodes are large. Such scales are characteristic of individuals which are at early ontogeny when the scaly cover is just beginning to form (seen in living sharks).

Stage II, juvenile scales: Instead of shedding scales of the first stage, a crown of a slightly larger size is laid down. The number of odontodes increases (if the scales consist of many odontodes). Below, in the anterior part of the scale the laminae of the basal plate begin to form, and rudiments of the basal ascending (secondary) canals or basal canal of monodontodia appear. During ontogeny, a small thickening of the basal plate lamina occurs. It does not yet reach the final size of the ventral surface of the crown. A net of horizontal canals can begin to form on the boundary between crown and basal plate. Dieing and shedding of scales begins when the pulp cavities of odontodes grow over (examples - juvenile scales of thelodontids, Elegestolepis and mongolepidids) (see Figs 10, 11).

Stage III, young scales: Still larger crowns are formed in the place of the shed scales of the sec-

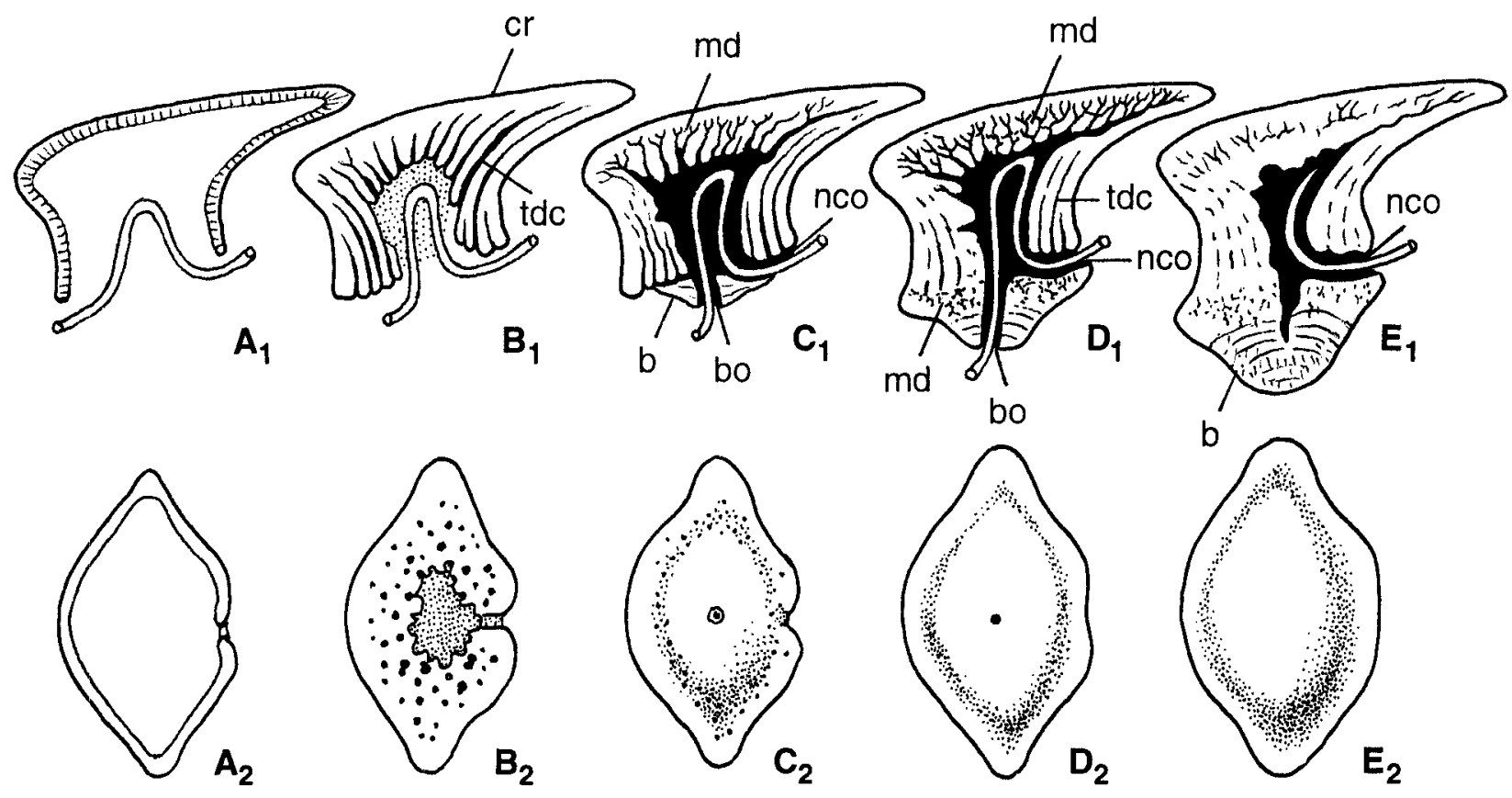

Fig. 10. A-E, ontogenetic development of the scale of Elegestolepis grossi Karatajute-Talimaa. $\mathbf{A}_{1,2}$, papilar stage; $\mathbf{B}_{1,2}$, juvenile scale without base; $\mathbf{C}_{1,2}$, juvenile scale with small base; $\mathbf{D}_{1,2}$, adult scale; $\mathbf{E}_{1,2}$, adult (old) scale;

b - base; bo - base opening; cr - crown; md - mesodentine; nco - neck canal opening; tdc - thick dentine canal (after Karatajute-Talimaa 1977, fig. 5A-E) 
ond stage. The odontode number in polyodontode scales increases considerably. The length of odontodes increases. The lamina of the basal plate becomes thicker, particularly in the center
(Elegestolepis) or in its anterior part (Mongolepis, Teslepis), and covers the whole surface. The pulp canal (of Elegestolepis) or ascending canals (of Mongolepidida) are numerous and wider in

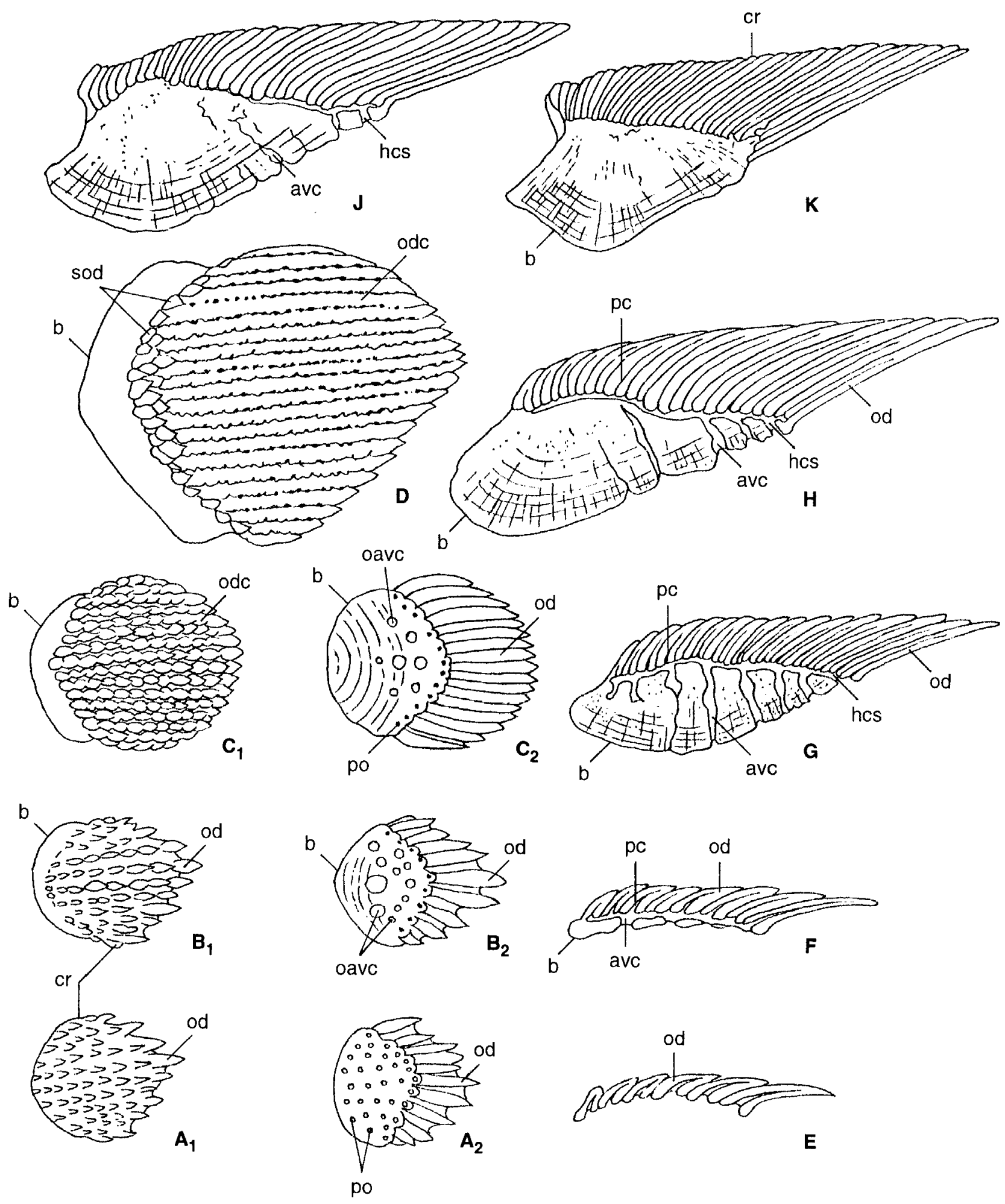

Fig. 11. Four stages in ontogenetic development of synchronomorial scales of Mongolepis rozmanae Karatajute-Talimaa et Novitskaya. $\mathbf{A}_{1,2}, \mathbf{E}$, papillar stage (I); $\mathbf{B}_{1,2}, \mathbf{F}$ and $\mathbf{C}_{1,2}, \mathbf{G}$, juvenile stages (II, III); $\mathbf{D}, \mathbf{H}$, adult stage (IV); J, K, adult (old) stage (IV a). $\mathbf{A}_{1}, \mathbf{B}_{1}, \mathbf{C}_{1}, \mathbf{D}$, view from above; $\mathbf{A}_{2}, \mathbf{B}_{2}, \mathbf{C}_{2}$, view from below; $\mathbf{E}-\mathbf{K}$, vertical longitudinal sections; avc - ascending vascular canal; $\mathbf{b}$ - base; $\mathbf{c r}$ - crown; hes - horizontal canal system; oavc - opening of ascending vascular canal; od - odontode; odc - "odontocomplex"; pc - pulp canal; po - pulp opening; sod - secondary odontode 


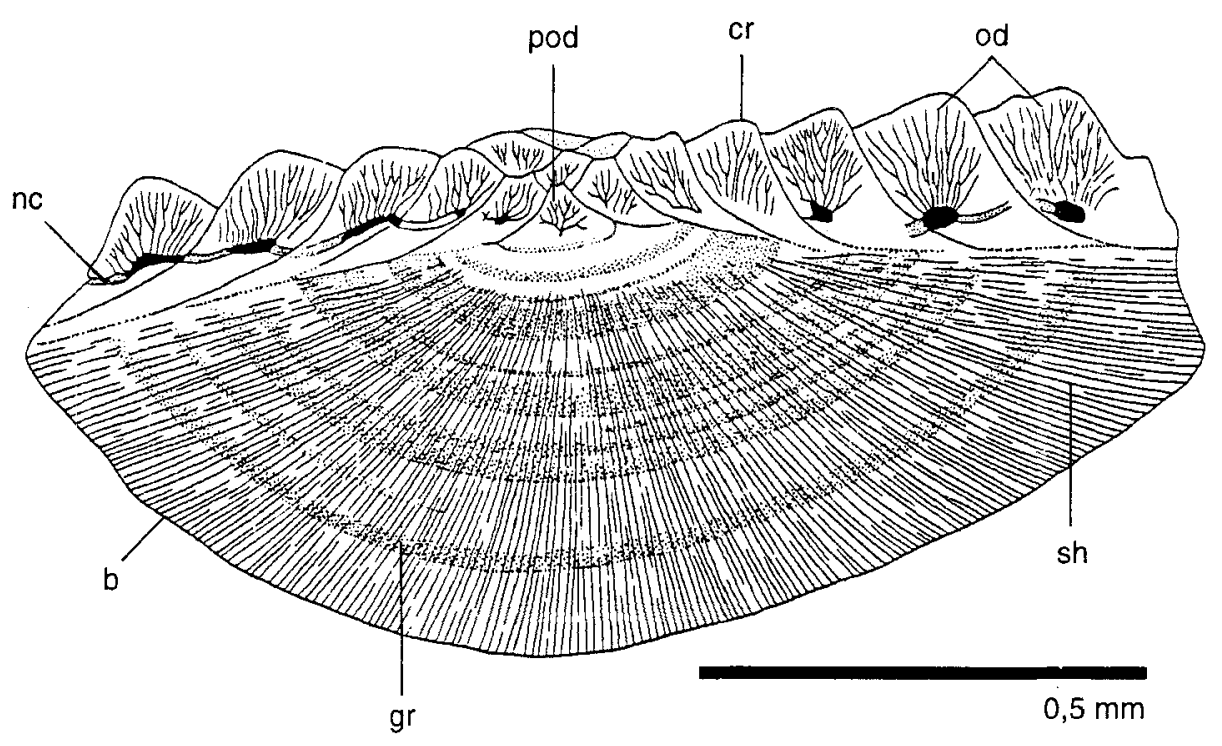

Fig. 12. Ohiolepis newberryi Wells, vertical cross section of scale. Growing scale of "Protacrodus" type;

b - base; cr - crown; gr growth line; nc - neck canal; od - odontode; pc - pulp canal; pod - primordial odontode; sh - Sharpey's fasers (after Gross 1973, fig. 21 C) the posterior part of the basal plate. A system of vascular canals (Mongolepis) is well developed (see Figs 10, 11).

Stage IV, mature scales: The crown is large. The number of odontodes composing the crown (polyodontodia), reaches the maximum (40-50). Pulp cavities of odontodes are narrower. The system of vascular canals (if it is present at all) becomes narrower. The basal plate is particularly high. Ascending (secondary) canals (of mongolepidids) are not always developed and only in the posterior part of the basal plate. The basal canal (of Elegestolepis, thelodontids) is comparatively narrow. Basal projections can be well formed in thelodont scales.

Old scales with highest density both in the crown and in the basal plate, belong to the fourth stage. Cavities and vascular canals are almost invisible and reduced (Fig. 11).

The ontogenetic development of squamation of Early Palaeozoic Chondrichthyes, which consist of scales with non-growing crowns, can be traced in material of Elegestolepis (KaratajuteTalimaa 1973) and mongolepids (Karatajute-Talimaa et al. 1990, Karatajute-Talimaa \& Novitskaya 1992).

Squamations which consist of growing scales or growing tesserae were increased either by the growth of the exoskeletal elements themselves or by addition of new ones.

Thus, four apparent stages can be determined in the ontogenetic development of squamation. The tesserae of astraspidid type development is very clearly represented in Tarlo's illustration (1967, fig. 2) (Fig. 13), where the following three stages are shown: I, separate rare tubercles growing centres (primordia) appear on the skin; large areas of "bare" skin remain among them. II, smaler tubercles appear (one, two areal zones) concentrically around the primordial tubercles, and circular tessera are formed; spaces of "bare" skin still remain in between. III, polygonal tesserae, in a continuous pattern, completely cover all skin areas. Further areal growth is often impossible. Stage IV of exoskeletal formation occurs in adult individuals, when development of polygonal tesserae is possible to the depth of the corium, in which thickening of the middle and basal spongy layers occurs, also upwards, at the expense of the epidermal lamina. Larger tubercles of later generations superimpose on already existing ones, and appear on the surface of the tesserae.

Another example of ontogenetic development of the squamation, which consists only of growing scales is that in the acanthodians (Fig. 14). Primordial, quite small, scales develop in the skin, probably during the embryonic stage of development. Further more centrifugal growth of scales by addition of spherical or semispherical plates occurs by incremental stages: growth lines are of first and second orders. The size of scales

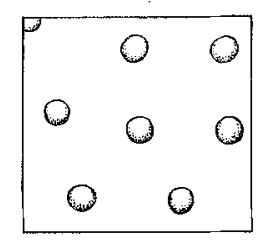

A

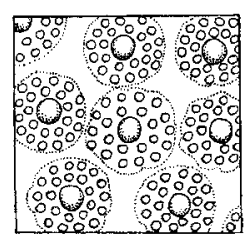

B

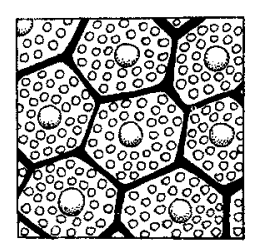

C
Fig. 13. Development of tesserae of cyclomorial growth. A, separate rare tubercles in the skin; $\mathbf{B}$, circular tasserae with two areal zones around the primordial tubercles; $\mathbf{C}$, fully formed polygonal tesserae (after Tarlo 1967, fig. 2) 


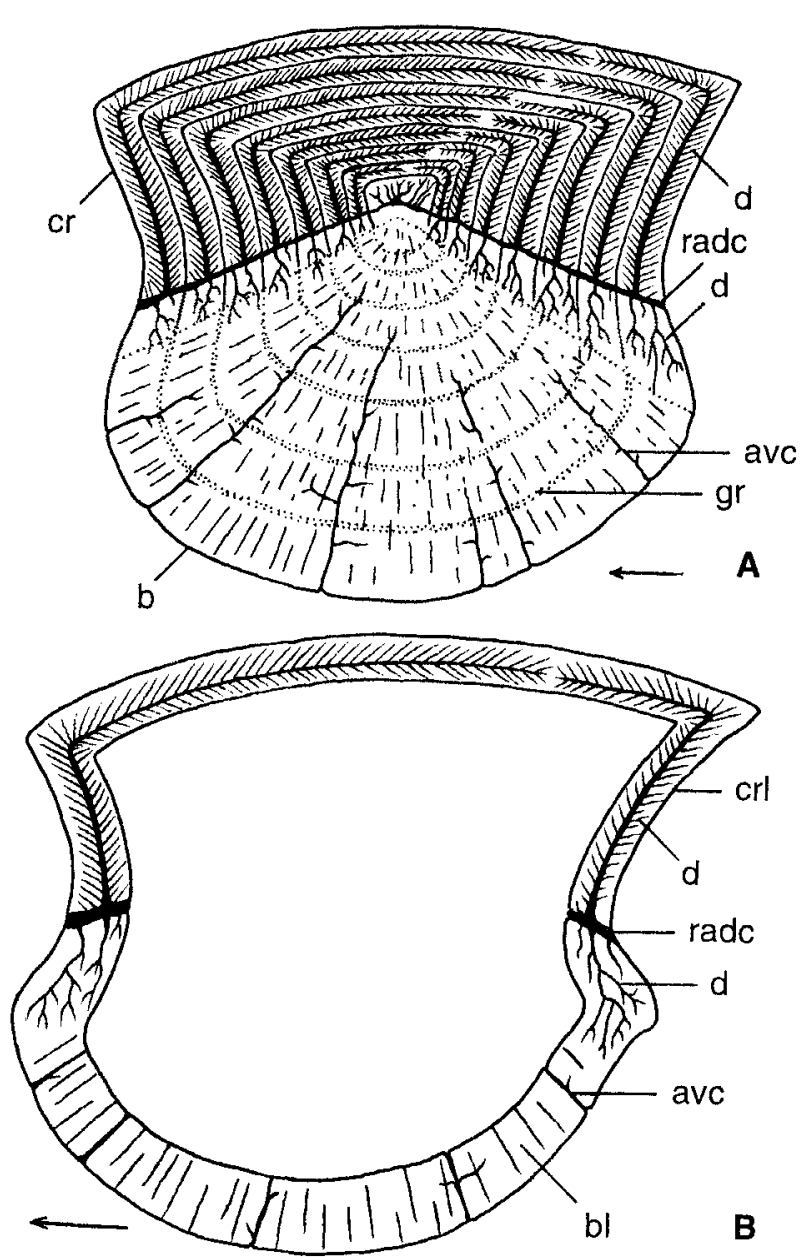

Fig. 14. A, inner structure of the scale of Acanthodes-Type; B, odontodium (Wachstumslamelle) in the scale of Acanthodes-Type;

avc - ascending vascular canal; $\mathbf{b}$ - base; $\mathbf{b l}$ - base lamelle; cr - crown; crl - crown; lamelle; d - dentine; gr - growth line; radc - radial canal (after Gross 1966, figs 2C, 3B)

increases repeatedly. To single out juvenile and young scales is relatively easy, depending on the number of growth plates. The size of these scales is small and medium. The squamation at the adult stage consists of completely formed scales. Scales, in which growth of the base continues to the depth of the corium and in which growth of their crown is no longer possible, have been found among Llandoverian primitive acanthodians (a new genus Karatajute-Talimaa et al. in prep.) (Fig. $15 \mathrm{~A}_{2-3}$ ).

A great variety of morphogenetic types of squamation have been recorded among chondrichthyans. The Protacrodus type (Reif 1978) has an invariable number of scales, so it is possible to assume the same stages of formation of the squamation as in acanthodians.

Squamations of hybodontids and ctenacantids contain single odontodes and complex growing scales according to Reif (1978). It is possible to suppose that scales of all their developmental stages have been distributed in squamations at different stages of ontogenetic development. It is not so easy to separate individual stages of squamation development.

\section{Growth in exoskeletal micromeric elements}

The elementary unit of the dermal skeleton is the odontode (defined above). Originally, this was a papilla of a certain shape bordering a vascular loop arose at the boundary between epidermis and mesoderm (mesenchyme). Cells of the mesenchyme form dentine (or a protodentine) or a dentinoidal tissue, which is infrequently covered from the outside by a superficial enameloidal layer.

Form and size of an odontode which has arisen in such a way remains stable throughout growth. All further transformations occur inside the odontode. Odontoblasts, which form the dentine and/or dentinoidal tissue, retreat deep into the papilla, or, more exactly, deep into the pulp cavity, for all this, they have left their distally located processes in the newly formed layer. The gradual retreat of the odontoblast nuclei causes the formation of the laminated dentinoidal tissue pierced by dentine tubules, which usually are arranged perpendicularly to the laminae (at least in orthodentine and its derivates). The junction of several odontoblast nuclei led to the junction of dentine tubules (processes). Usually this phenomen is called "dichotomous branching of tubules". Centripetal growth of dentine or dentinoidal tissue led to a partial and later to an almost complete overgrowth of the pulp cavity.

This way all odontodes, whether consisting of orthodentine, irregular dentine, arboriform dentine, mesodentine or semidentine are formed. These tissues are characteristic of thelodont scales, tubercles of astraspid tesserae, ridges and tubercles of heterostracan plates and scales of many chondrichthyans including neoselachians. I suppose that the timing of the evolution of changes in various dentinous tissues was heterochronous.

However, there are odontodes consisting of atubular dentine (dentine tubules are absent) where only a thin lamination of the tissue is visible. Dentine laminae of this type are very thin, distributed parallel to the external walls of the odontode. Such an atubular dentine has been 

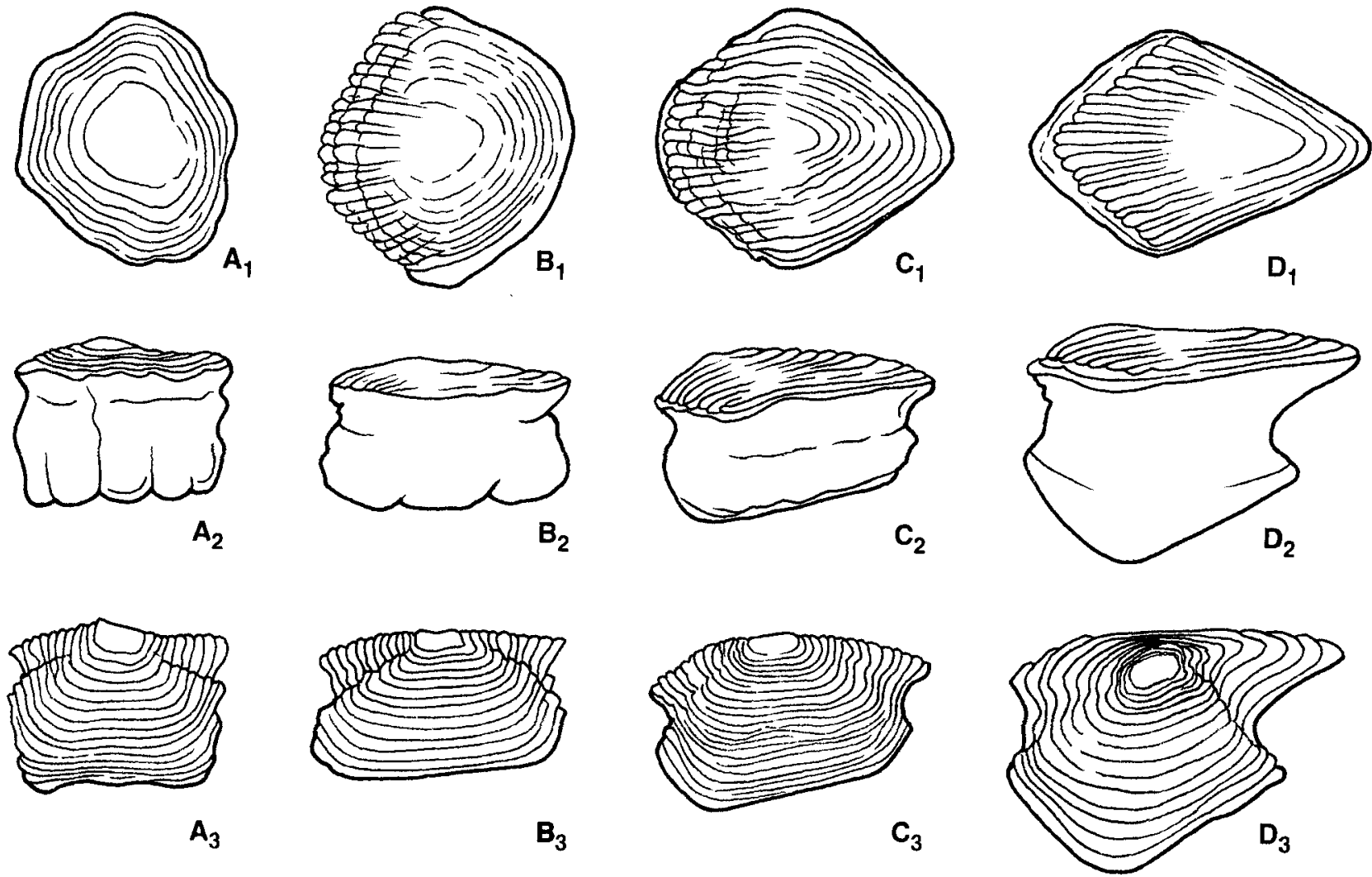

Fig. 15. Acanthodii gen.nov. 1. $\mathbf{A}_{1-3}$, head scale; $\mathbf{B}_{1-3}-\mathbf{C}_{1-3}$, transitional scales; $\mathbf{D}_{1-3}$, body scale. $\mathbf{A}_{1}, \mathbf{B}_{1}, \mathbf{C}_{1}, \mathbf{D}_{1}$, view from above; $\mathbf{A}_{2}, \mathbf{B}_{2}, \mathbf{C}_{2}, \mathbf{D}_{2}$, lateral view $; \mathbf{A}_{3}, \mathbf{B}_{3}, \mathbf{C}_{3}, \mathbf{D}_{3}$, vertical longitudinal sections, lines of growth; $\mathbf{A}_{3}, \mathbf{B}_{3}, \mathbf{C}_{3}$, areasuperpositional growth of crown; $\mathbf{D}_{3}$, superpositional growth of crown

called lamelline (Karatajute-Talimaa et al. 1990). Two models of formation of the lamelline may be suggested: 1) the odontoblasts (lamelloblasts) consist only of cells devoid of processes; 2) the lamelloblasts consist of cells with processes, which retreat into the pulp cavity of the odontodes during the formation of the lamelline lamina complex, without the processes becoming trapped and thus, to effect, dentine tubules do not form (Karatajute-Talimaa 1995). Odontodes consisting of lamelline are characteristic of the crown of scales of the Mongolepidida.

A vascular loop which supplied the odontode entered and returned only through the basal aperture. Alternatively, it entered the base and left from one side (lepidomorium Fig. 1A, B). As noted above, the first variant type odontodes are characteristic of some thelodont scales, dentine tubercles of astraspids, ridges of heterostracans and mongolepidids. Odontodes containing a vascular loop of the second variant are peculiar to the crown of chondrichthyan scales, and in a derived state to acanthodians and actinopterygian scales.

When an odontode containing one basal aperture or two apertures, basal and neck, reaches a certain stage of development and begins to func- tion as scale, it begins to accomplish protective and hydrodynamic functions. Then anchoring of the scale in the skin becomes necessary. An adherence of the basal bony laminae to the dentinoidal crown-odontode and anchorage in the mesoderm by Sharpey's fibres takes place. Such on odontode should already be called odontodium (monodontodium). This is taken to extreme in thelodont bases (Fig. 16).

Further growth of the basal plate deep into the corium led to a gradual overgrowing of the basal canal, with aging of the scale and consequent shedding. The neck canal in placoid scales of Elegestolepis type does not overgrow (Karatajute-Talimaa 1973) since it is located on the boundary between crown and basal plate (Fig. 10).

The odontode in acanthodian scales is very different in its form from that described above. The primordial acanthodian scale originates at the boundary between epidermis and mesoderm, and consists of dentinoidal crown and bony basal plate (with or without bone cells). In essence it is not an odontode, but an odontodium (monodontodium), since its crown is set on a basal plate (see Fig. 14B). 


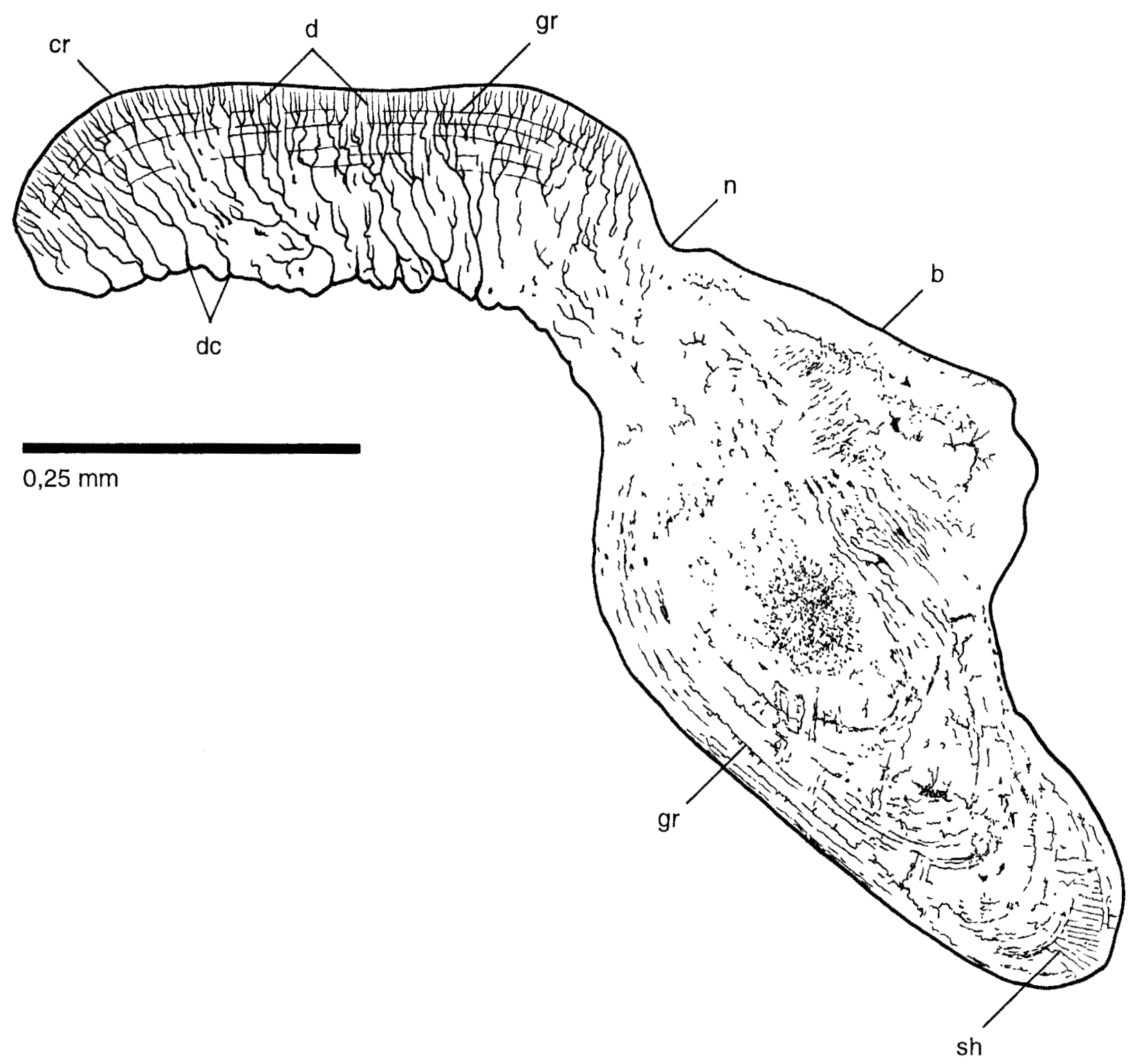

Fig. 16. Helenolepis obruchevi Karatajute-Talimaa. Body scale with well developed base (vertical longitudinal sections); b - base; cr - crown; d - dentine; de - dentine canals; gr - growth lines; $\mathbf{n}$ - neck; sh - Sharpey's fasers (after KaratajuteTalimaa 1978, fig. $15_{7}$ )

The odontodium of the second generation is formed by a spherical or semispherical plate, which envelops the primordial scale. Odontodia of the next generations overgrow centrifugally, and the scale increases its size gradually. Gross (1966) represented the acanthodian odontodium in the form of a spherical plate, the upper part of which consists of dentinoidal tissue, and its lower part of bony tissue. Ascending canals which diverge from the radial canal and are located at the boundary between crown and basal plate, are disposited in the upper part of the plate (crown). Essentially, a horizontal canal (usually very short within the plate limits) corresponds with the odontode neck canal. Consequently, the ascending canal is an analogue of the pulp cavity of the ordinary odontode. Since there are many such canals in the spherical (or semispherical) plate around the periphery of the crown, the latter ought to be regarded as polyodontodium. Neck canals of growth plates of different generations and in the neck region the system of neck canals are joined with the vascular system of mesoderm.

As material of Llandoverian acanthodians from Central Asia shows (Karatajute-Talimaa et al. in prep.), crown growth of part of the scales has occurs by centrifugal addition of semispherical but not spherical new zones (see Fig. $15 \mathrm{~A}-\mathrm{C}$ ). Consequently, the crown grows not superpositionally, but increases concentrically by areal growth and its height does not changed. 
Such areal growth of the crown is found in tesserae, which cover the head of early acanthodians (ordo nov., Climatiida). However, they develop a system of separate dentine tuberclesodontodes instead of complete plates along the periphery.

Areal and partly superpositional growth of the crown is presented in scales such as polyodontodia of elasmobranchs of the morphogenetic type Protacrodus (Gross 1973). Scale crowns grow by addition of new odontodes around the primordial one. For all this, the initial, primordial odontode can frequently be covered by superimposed odontodes of a second and even a third generation (see Fig. 12). Areal zones are composed of odontode-tubercles or odontode-ridges, which can be long enough but never form an entire ring, as in Llandoverian acanthodians.

The basal plate of the Protacrodus type is always convex and grows by an increasing number of entire semispheres, growth plates deep into corium. Usually, one plate of basal plate growth corresponds to each zone of crown growth.

Crown growth of the morphogenetic type Altholepis elasmobranch scales (Karatajute-Talimaa 1992, 1997c) occures by increase of odontode numbers on each side and behind the primordial odontode. The basal plate is slightly concave, cone-shaped within the scale (Fig. 17).

The above considered examples of micromeric scales, placoid and complicated - growth, illustrate both non-growing and growing crown formation. The basal plate can also be non-growing and growing. According to these indications, the micromeric scales can be classified as follows:

1. Non-growing crown and non-growing basal plate: Examples, are complex crowns of syn- chronomorial Polymerolepis type, ctenacanthid and edestid scales.

2. Non-growing crown and growing basal plate: Examples, are most scales of thelodonts, elasmobranchs scales of Elegestolepis and Mongolepidida type: the crown can be formed of one or many simultaneously formed odontodes.

3. Growing crown and growing basal plate: Examples, are a great number of Palaeozoic elasmobranchs, including Protacrodus type, tesserae and scales of acanthodians, tesserae of atraspids and Tesakoviaspis.

4. Growing crown and non-growing plate: Examples, are Hybodontidae; the growth variant here given ought to be understood as increase of subsequent generations of odontodia but not odontodes, when crown elements, set on small plate of basal plate, adhere. During scale growth, the basal plate increases not deep into the corium, but along its periphery.

5. Exoskeletal elements, composed completely of bony tissue, having no cells, or containing bone cells, the only growth is deep in the mesoderm, centrifugally from the scale primordium, examples are tesserae of a new genus from upper Llandovery of Siberia.

Elements of the dermal skeleton, may be derived from an initial stage and are formed at the same time, synchronomorial, or by means of subsequent growth of the crown, cyclomorial.

Scales, monodontodiums (simple or complex) and polyodontodiums, with crowns which originate simultaneously, belong to the first group. External shape and size of the crown do not change during the process of scale ontogenetic development. Only the basal plate can grow. Already described placoid scales of elasmo-

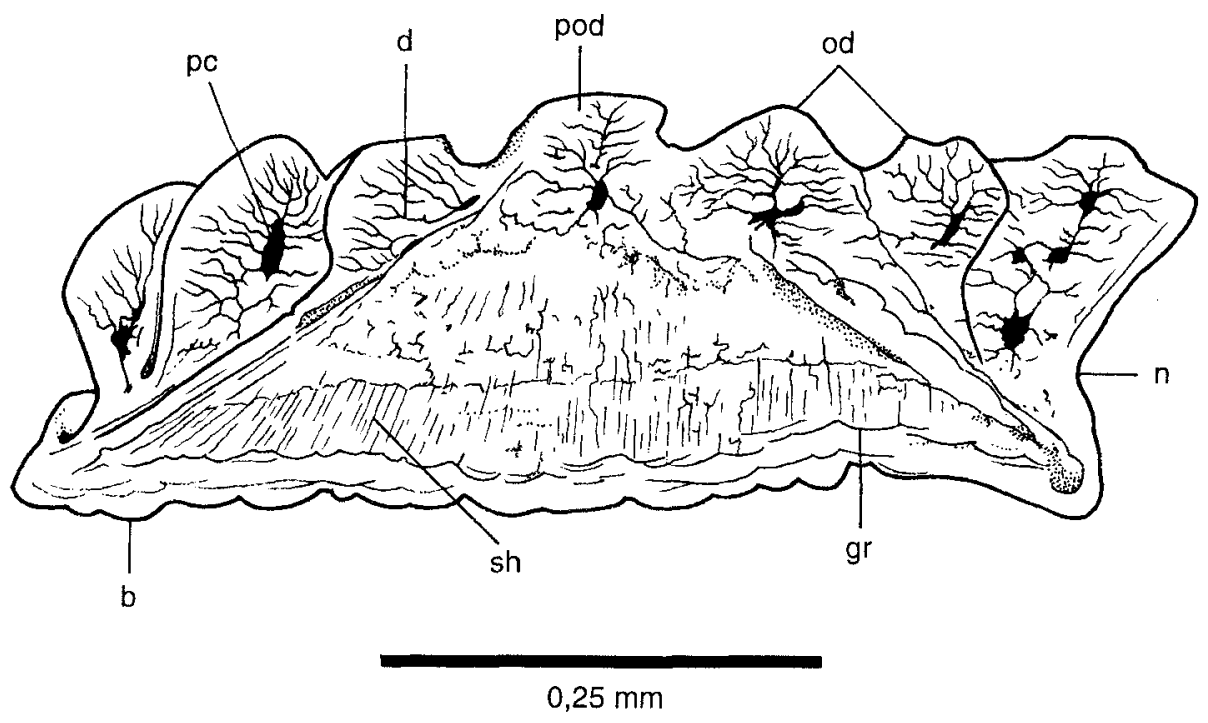

Fig. 17. Altholepis composita Karatajute-Talimaa. Vertical cross section of scale; b - basal plate; d - dentine; gr - growth line; $\mathbf{n}$ - neck; od - odontode; pc - pulp canal; pod - primordial odontode; sh - Sharpey's fasers (after Karatajute-Talimaa 1997c, fig. 4A) 
branchs of Elegestolepis type are an example of simple monodontodia. The complex monodontodia are formed on papillar stage and consist of some odontodes, merged into an individual crown, covered by an entire dentine layer. Scales of such a type have a complex pulp cavity, subdivided by partitions into small separate cavities (e.g. edestides scales and scales of Polymerolepis type). They are joined among themselves by vascular canals. The basal plate is quite low, having the shape of thin border, and is concave in the middle. In its central part the basal openings are visible and are not overgrown even on fully adult scales. In the neck area of such scales the neck openings are very distinct (Figs 6-8).

The scales of mongolepidids and elasmobranchs of the genus Lugalepis illustrate polyodontodes of synchronomorial origin (KaratajuteTalimaa 1992, 1997a). Crowns of this type of scale consist of a great number of odontodes. Odontodes of mongolepidids are grouped into longitudinal lines and overlie each other ("odontocomplexes"). Odontodes of Lugalepis are comparatively low, spiniform, distributed not so densely and rather disordered or forming oblique lines.
The crowns of mongolepidid scales form simultaneously as many separate odontodes, each with centripetal filling of the pulp cavities by lamelline layers. The basal plate appears later, as the bone of attachment in scale development when attachment to the corium occurs (Fig. 11). It appears on the anterior part of scale and is later overgrown by thin laminae, paving the whole lower surface of the crown and gradually the odontode pulp cavities. Within this basal plate secondary cavities are formed as vascular vertical canals, which gradually narrowed, until later they become completely overgrown. The vascular supply to the pulp canals is either by basal ascending canals (genus Sodolepis) (Fig. 18 ), or through a horizontal net of canals ( $T e$ slepis, Mongolepis, Figs 19, 20). Both basal and horizontal canals become closed by overgrowth. When a scale can no longer function it is condemned to be shed.

Basal plates of all age stages of the genus $\mathrm{Lu}$ galepis remain concave or flat and consist of a comparatively thin spongy layer and a very thin basal lamina. The basal plate of such a type can be formed in the mesoderm below the crown, and later be attached to the crown. Apparently,

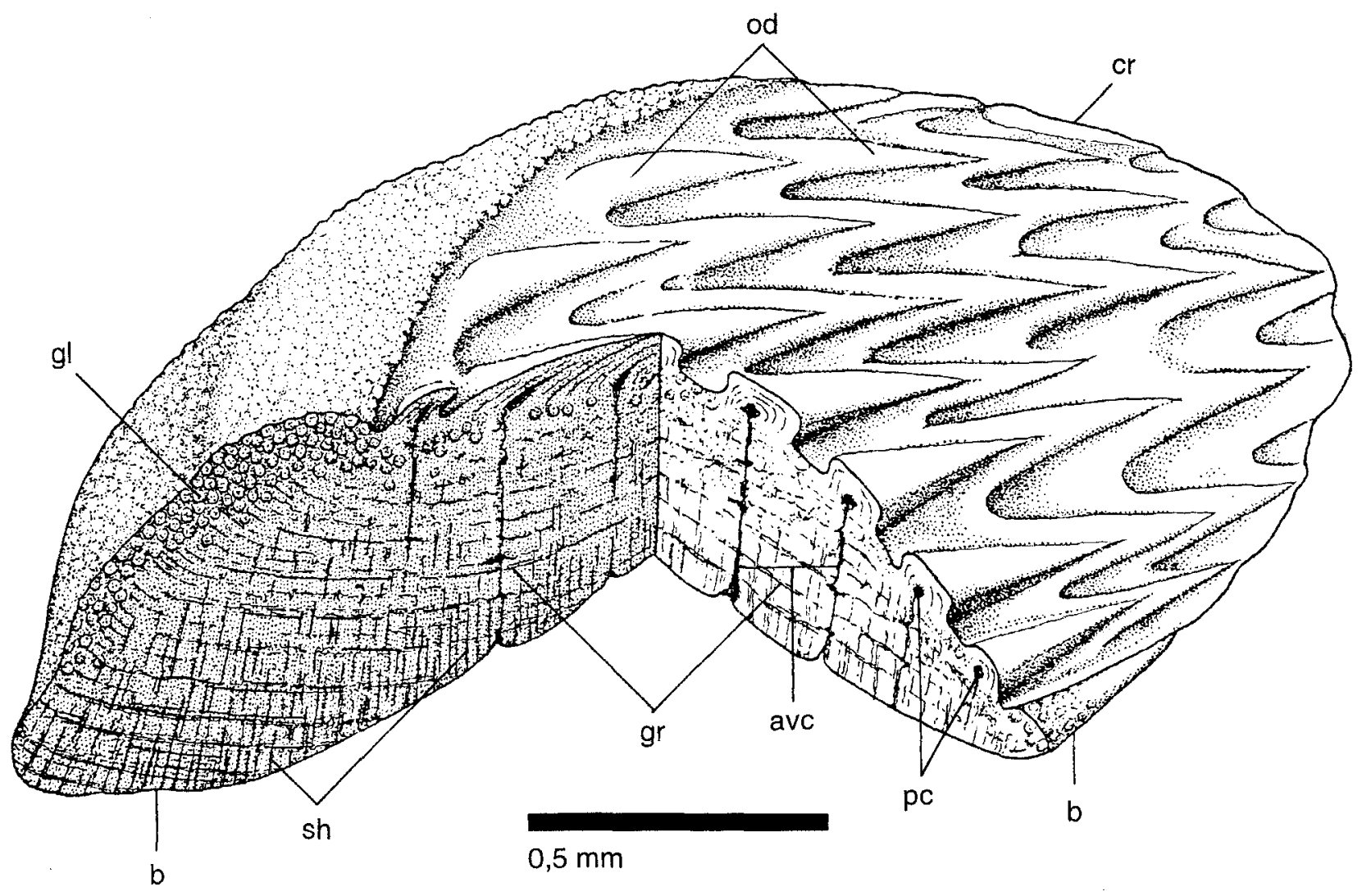

Fig. 18. Three-dimensional diagram illustrating the structure of a scale of Sodolepis lucens Karatajute-Talimaa et Novitskaya; avc - ascending vascular canal; b - base; cr - crown; gl - globular tissue of base; gr - growth lines; od - odontode; pc pulp canal; sh - Sharpey's fibres 


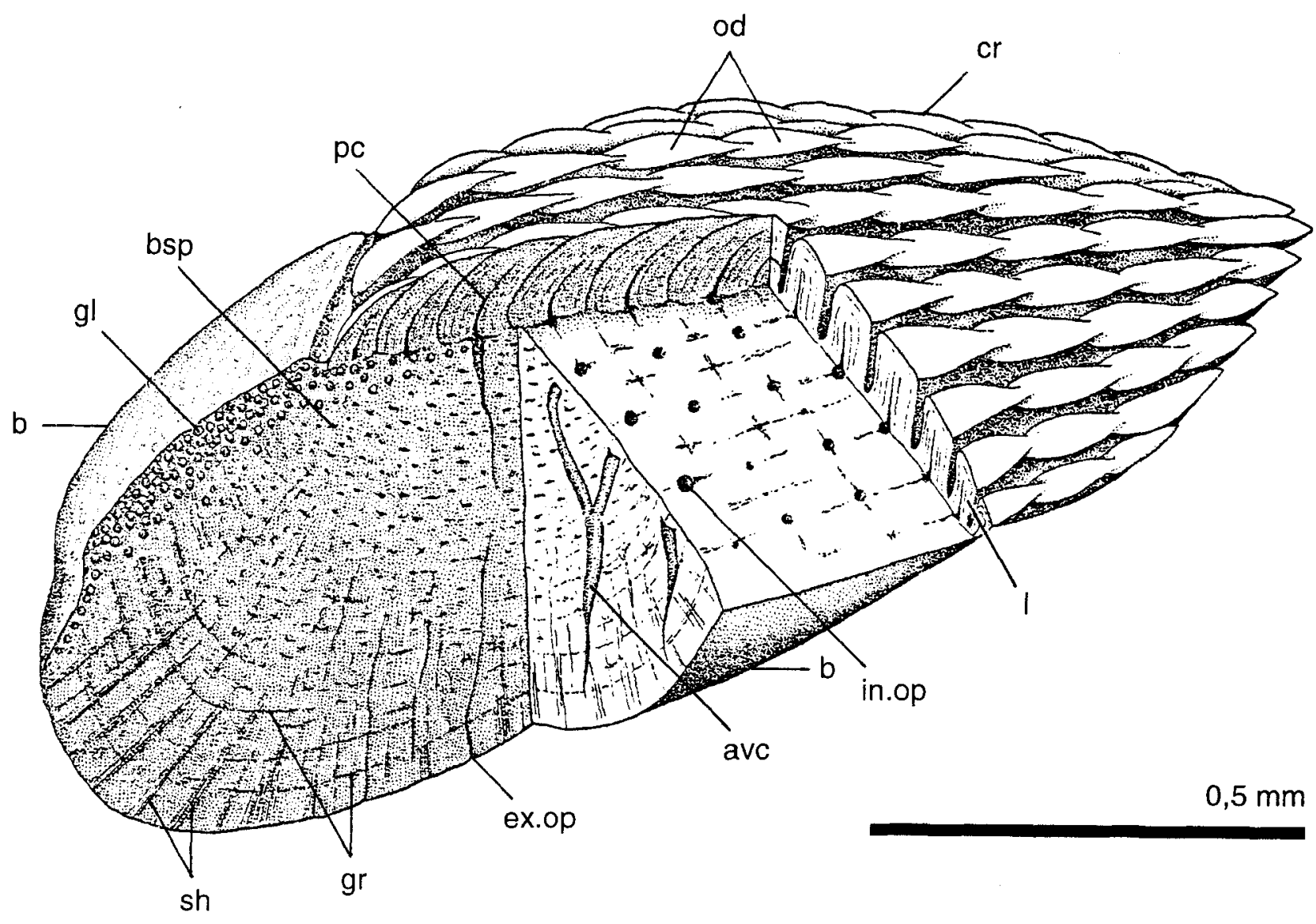

Fig. 19. Three-dimensional diagram illustrating the structure of a scale of Teslepis jucunda Karatajute-Talimaa et Novitskaya; avc -- ascending vascular canal; b - base; bsp - bone spaces; cr - crown; ex.op - external opening of crown; gl - globular tissue of base; gr - growth lines; in.op - internal opening of avc; 1 - lamelline in odontode; od - odontode; pc - pulp canal; sh - Sharpey's fibres

nevertheless, the basal plate of this type is nongrowing, because extra horizontal growth layers are not found.

Scales, tesserae and plates of cyclomorial growth have been developed in representatives of several groups of lower vertebrates, astraspids, Tesakoviaspis, heterostracans, acanthodians, elasmobranchs, actinopterygians. Stensiö (1961, 1962) distinguished stiphronal and churtonal cyclomorial scales. In the first group odontodes (or, more precisely, odontodia) of each growth zone fit closely to each other both in crown area and on the basal part (look at determination on p. 23). Odontodes of the second group are distributed on the crown at some distance from each other in the form of individual tubercles or appendices. These two varieties of cyclomorially growing exoskeletal elements, however, are not mentioned in modern studies of other investigators.

Stensiö (1961: figs 1, 2; 1962: pl. I, II) has used the scales of Late Permian edestid, as an example of cyclomorial growth, and has illustrated this process with a great number of pic- tures. In Figs 2-4 the examples of stiphronal and churtonal variants of cyclomorial scale growth are represented.

In my Lower Palaeozoic material from Siberia the cyclomorial growth is best illustrated by the example of Tesakoviaspis tesserae (Fig. 21). Tesserae of $T$. concentrica Karatajute-Talimaa (1978) represent all stages of tesserae formation by addition of one, two, or more concentric areal zones of odontodes around a primordial one. The sample from the location of the river Lower Tchunku (Moskalenko 1968) contains scales with only one individual primordial tubercle with round or oblong tear dropshaped crown, a small ring of basal plate and a wide pulp cavity. This does not differ essentially from simple thelodont scales. Also present are tesserae, which consist of a primordial tubercle and joined to it on one side one, two or three tubercles, smaller in size, which, however, do not form a complete areal zone. Pulp cavities, surrounded by a low basal plate, are visible from below under each tubercle.

Tesserae are also found with two and three areal zones of growth, and round contours 


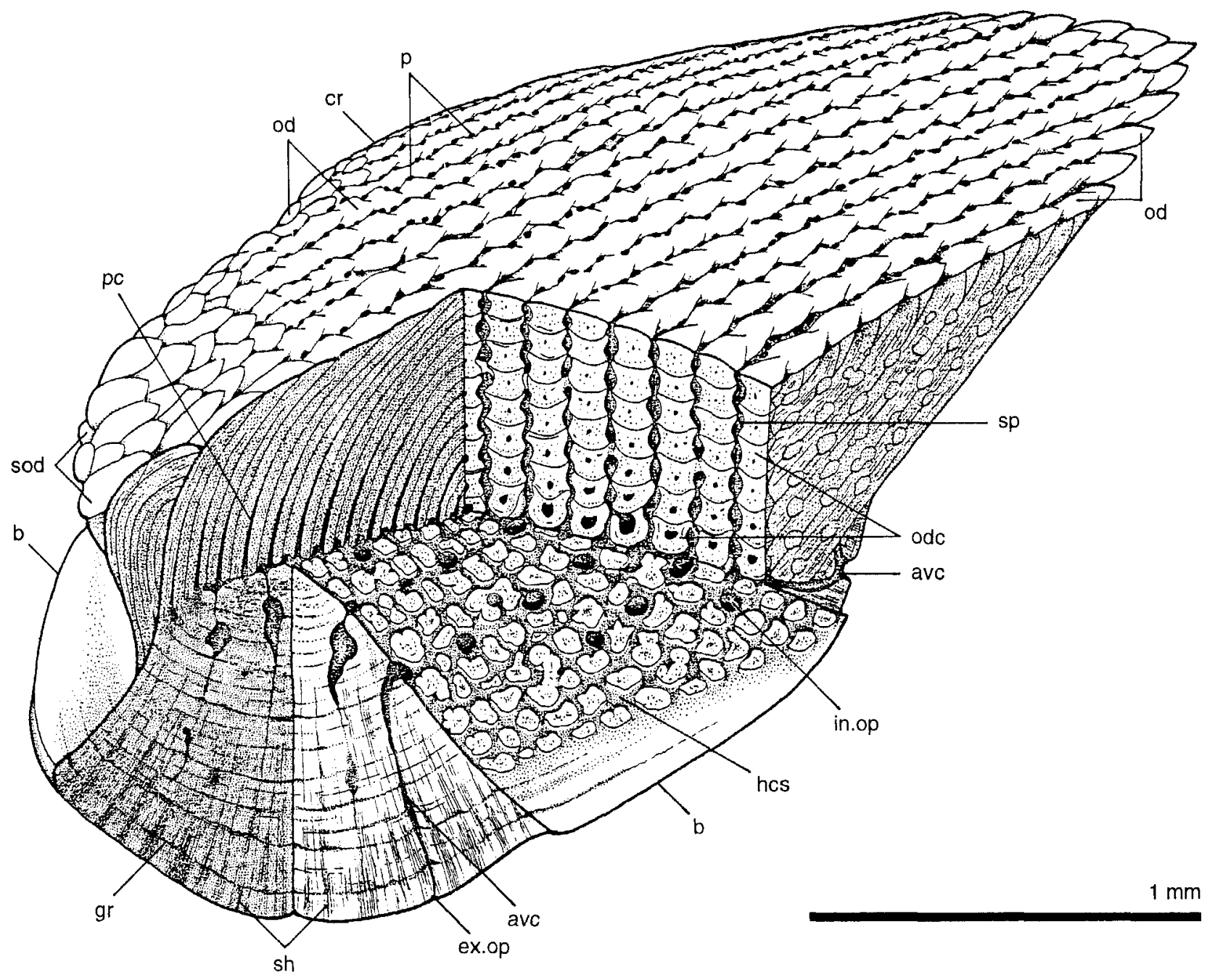

Fig. 20. Three-dimensional diagram illustrating the structure of a scale of Mongolepis rozmanae Karatajute-Talimaa et Novitskaya;

avc - ascending vascular canal; b - base; cr - crown; ex.op - external opening of avc; gr - growth lines; in.op - internal opening of avc; od - odontode; odc - "odontocomplex"; p - pores on the surface of the crown; pc - pulp canal; sh Sharpey's fibres; sod - secondary odontode; sp - space between the "odontocomplex" (after Karatajute-Talimaa 1995, fig. 1).

(circular tesserae). Tesserae with concentric zones of tubercles appear only at the later stages of growth (Fig. 21). The entire basal layer grows at a late stage of ontogenetic development when the basal layer closes the pulp cavities and reaches a considerable thickness, especially on polygonal plates. The basal plate continues to grow into the corium even after tesserae have completely formed borders. Limited material on polygonal tesserae prevents judgement about development of spongy laminae in tesserae of Tesakoviaspis, which is not unlike tesserae of Astraspis and Pycnaspis. Tubercles of later generations, very characteristic of astraspids from North America, are not yet found on the crown of Tesakoviaspis tesserae.

In the upper Llandoverian deposits from the Irkutsk amphitheatre, tesserae consisting of aspidine only and no dentine, have been found. Ap- parently, tesserae of this new genus are formed completely, including sculptural tubercles on the surface within mesoderm.

\section{Squamation}

The exoskeleton of different early vertebrates consists of micromeric scales and tesserae, mesomeric scales and tesserae and macromeric plates. It is the most difficult to reconstruct an exoskeleton consisting of micromeric elements which are found as separate scales in fossil deposits. It is necessary to find an analogy among preserved fossil intact specimens or among contemporary forms to determine the taxonomic types of scales and the squamation. It is necessary to restore, even if only roughly, topographic variation in the squamation and to represent all possible mor- 


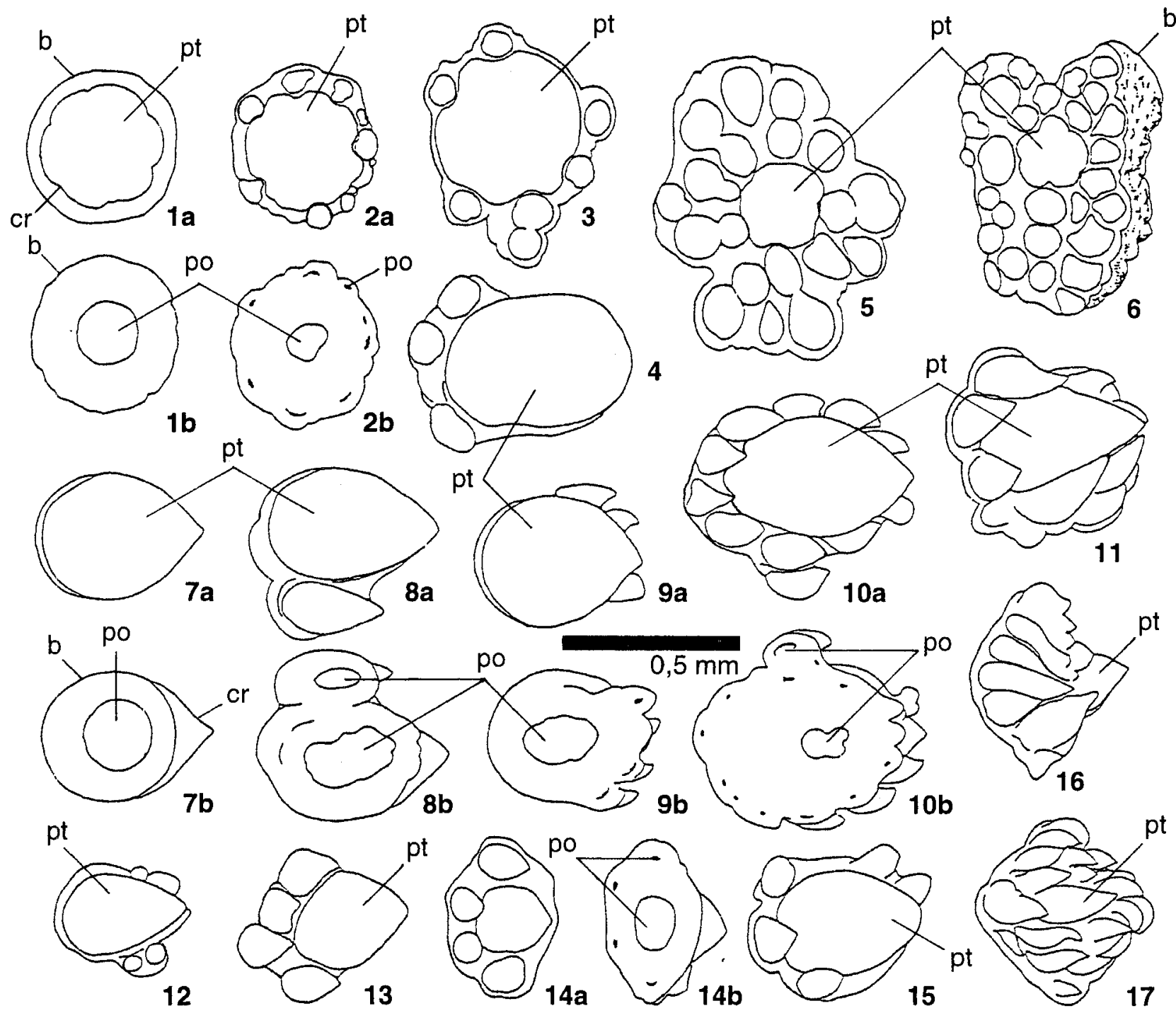

Fig. 21. Tesakoviaspis concentrica Karatajute-Talimaa. Morphological set of tesserae;

1 a, b; 7 a, b - single primordial tubercles; $4 ; 8$ a, b; 9 a, b; 12; 13 - tesserae with uncompleted first areal zone of growth; 2 a, $\mathbf{b} ; \mathbf{3} ; \mathbf{5} ; \mathbf{1 0} \mathbf{a}, \mathbf{b} ; \mathbf{1 1} ; \mathbf{1 4} \mathbf{a}, \mathbf{b} ; \mathbf{1 5} ; \mathbf{1 6} ; \mathbf{1 7}$ - circular tesserae with one or several areal zones of growth; 6 - polygonal tessera with thick base.

b - base; cr - crown; po - pulp opening; pt - primordial tubercle

phological varieties of discrete scales or tesserae by forming a morphological set for each proposed species.

Below I shall consider different variants of the squamation by example from groups of lower vertebrates: thelodonts, astraspids, Tesakoviaspis, acanthodians and elasmobranchs.

Thelodonts. Thelodont scales, forming a dermal cover (exoskeleton) have the following morphological characters - common form, presence or absence of sculptural elements, proportions between crown and basal plate, size and lenght of rear part of crown and anterior part of basal plate. They are subdivided into main morphological varieties (types):
1. "Kopfschuppen" (Gross 1967), "head scales" (Turner 1976), "cephalic scales" (KaratajuteTalimaa 1978) and "oral", "cephalo-pectoral" (Märss 1986a);

2. "Übergangsschuppen" (Gross 1967), "transitional" (Turner 1976), "transitional" (Karatajute-Talimaa 1978), "cephalo-pectoral" (Märss 1986a);

3. "Rumpfschuppen" (Gross 1967), "body scales" (Turner 1976), "body scales" (Karatajute-Talimaa 1978), "post-pectoral and precaudal" (Märss 1986a).

4. One more morphological variety "pinnal" scales on fins has been established by Märss (1986a). 
5. Sensory scales. "Porenschuppen" (Gross 1968), lateral line scales, pore-canal scales (Karatajute-Talimaa 1978, Märss 1986b, Turner 1991).

Special scales (Gross 1967, 1968, Märss 1986 a, b, Turner 1991, Turner \& Van der Bruggen 1993:

6. Orbital

7. Rostral

8. Branchial bucco pharyngial.

The material, which was used by Gross (1947, 1967) and enabled him to establish three main varieties of thelodont scales, consists of intact specimens of British forms - Loganiidae and Turinia. Turner (1982, 1984, 1986, 1991, 1992) studied the Scottish, American and English intact specimens of Loganellia, Lanarkia and Turinia. Märss (1986a, b) studied the squamations of intact specimens of Phlebolepis elegans, following it compiling morphological sets of scales has become more established. Nevertheless using her distinctions for varieties of scales is not always practical, it is easier to subdivide thelodont scales into head or cephalic, transitional, body, sensory and specialised or internal scales.

It turns out, that the head scales of different genera and species have rather similar forms, and this is why Gross (1967) has paid greater attention to the body scales for determination of discrete material.

The head scales of most thelodonts, with the exception of Early Devonian representatives Nikoliviidae and Apalolepididae, also the Silurian Phlebolepis, have a smooth crown, sometimes heavily notched on its edges, round, oval or polygonal. The presence of such scales in the morphological set is evidence of the availability of areas with a mosaic, dense set of exoskeletal elements in the squamation. The notched edges of their crown link them together more firmly. Evidently, these body areas are more immobile.

The anterior part of the thelodont body, including part of the head area, is covered by scales with sculpture, particularly on the anterolateral areas of the crown. The cephalo-pectoral, or simplified-transitional scales, are attributed to this group. The transitional scales with two lenghtwise grooves in the anterior part of the crown, notched posterior lateral edges, and a flat smooth posterior part of the surface are found in the squamation of Loganiidae.

Either lenghtwise sculpture, ridges and fissures, or a diamond-shaped flat and smooth central section of the crown with lateral spinules on the postero-lateral parts, directed backwards, are developed on body scales of almost all genera of thelodonts. Undoubtedly, all these morphological elements of crown fulfill hydrodynamic functions, aiding lamination of water flow thus reducing turbulence and increasing swimming efficiency.

The narrow oblong form, small size and well expressed lengthwise sculpture in combination with spiny postero-lateral edges, are characteristic of precaudal and pinnal scales, disposed on the rear part of the body at the level of dorsal and anal fins, and of scales covering the surface of the caudal fin (Märss 1986a: fig. 5).

The squamation of thelodonts develops and functions, apparently, according to the same principles as that of chondrichthyans with non-growing crowns as Elegestolepis, or the recent elasmobranchs. Thelodont scales with non-growing crowns and growing (by different degree) basal plates, undoubtedly are shed, making room for new, larger scales. Skin growth is compensated by increased size of substituting scales and by fixing the new ones. This increases the total number of scales on the body. The last conclusion, drawn by analogy with elasmobranch squamations, has been corroborated by studies of intact specimens (Turner 1992, Märss \& Ritchie 1998).

The new material of Late Ordovician and Early Silurian thelodonts from North Eurasia, provides new data to explain their squamations.

The genus Sandivia is represented by discrete scales of a greatly unusual form (Karatajute-Talimaa 1997b). In morphological sets, it is sometimes easy to distinguish head, transitional and body scales (Fig. 22). Typical head and body scales are so different in form, that originally they were attributed do different groups - heterostracans and thelodonts (Talimaa \& Melnikov 1987).

The cephalic scales of the genus Sandivia, flat, sometimes convex tubercles are characterized by completely smooth crowns, with smooth or notched edges, very large and shallow, open pulp cavities, surrounded by a low ring of the basal plate. Such crowns are externally more reminiscent of primordial tubercles of astraspides or of Tesakoviaspis, than of head scales of thelodonts.

The body scales are long and narrow (see Fig. 22). The posterior anchor-shaped area of the crown and medial lenghtwise ridge are very peculiar. The basal plate is notdeveloped or very thin. Aspidine laminae form only a very low wall surrounding a large and shallow pulp cavity. The increased area of the crown's lower wall, which 


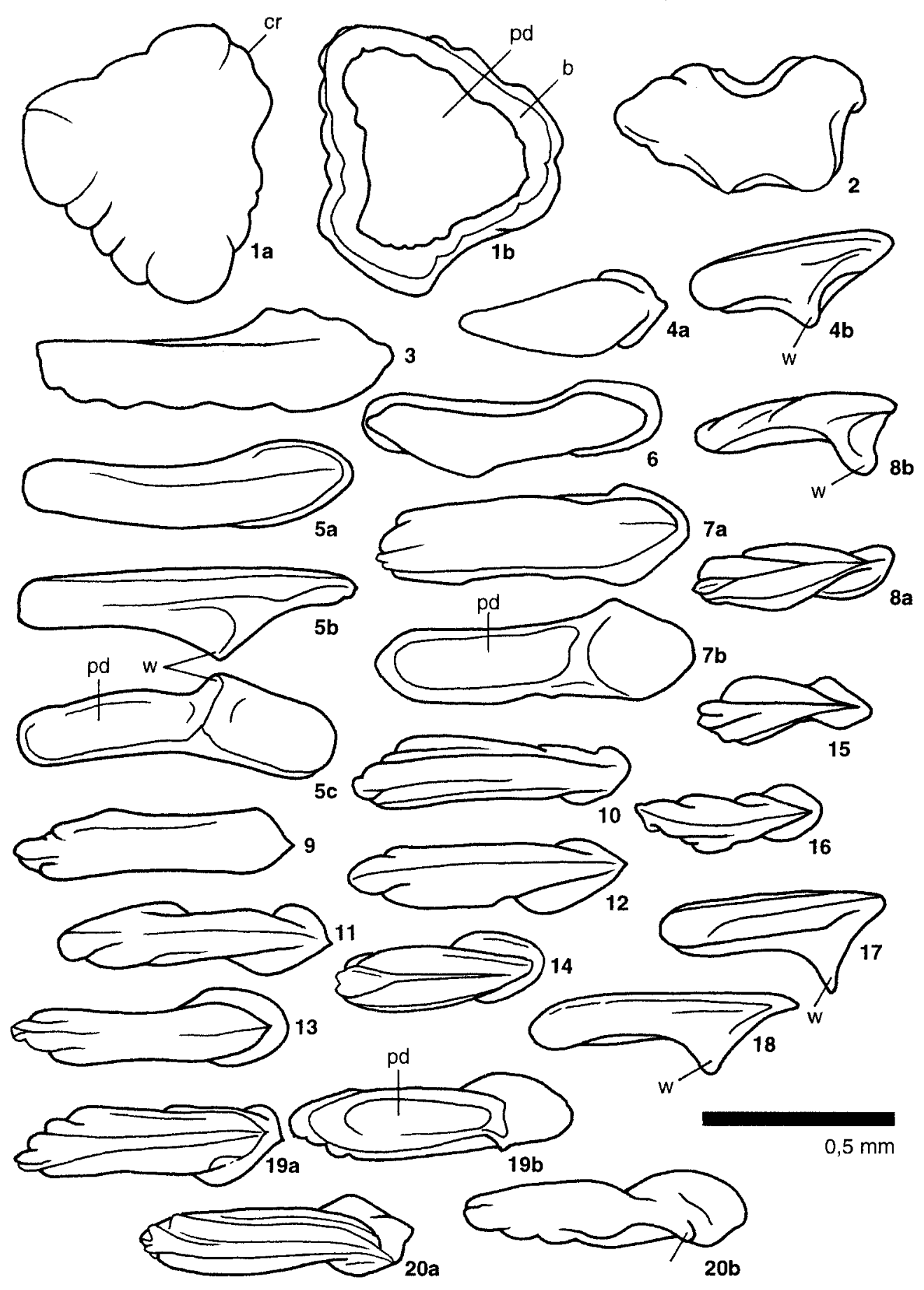

Fig. 22. Sandivia angusta Karatajute-Talimaa. Morphological series of scales;

b - base; cr - crown; pd - pulp depression; w - vertical wall (after Karatajute-Talimaa 1997 b, fig.4)

surrounds the pulp cavity from posterior, is most unusual. It is transformed into a peculiar "anchor" to fasten the scales somehow into the skin. Apparently, such scales were not densely arranged in the skin, because the sloping, posterior part of the crown is large and broad.

The unusual form of the scales of Sandivia prevents an assumption of lifestyle and habitat of its representatives. Most likely, they have been nectobenthonic forms with a firm (mosaic) squamation on the anterior part of body and more mobile on the posterior part. It is hard to imagine, that the representatives of this most ancient genus of loganiid thelodonts are excellent swimmers. Scales of Sandivia have much in common with those of Valyalepis (Turner in Turner \& Nowlan 1995) from the Lower Silurian of Quebec, Canada.

The Early Silurian thelodonts from Siberia, Tuva and Mongolia are represented by three 
genera, Angaralepis, Loganellia and Helenolepis. Angaralepis moskalenkoae (Karatajute-Talimaa 1997b) has very small characteristic diamondshaped scales with a strong lenghtwise sculpture. The posterior, anchor-shaped crown area is developed on body scales of Angaralepis moskalenkoae. Apparently, such a morphological element, developed on scales of genera Sandivia and Angaralepis, is not particularly "progressive" (successful), because it is not found on any Late Silurian and Devonian thelodont.

Squamations of the genus Loganellia have been intensively studied using intact specimens (Turner 1992, Turner \& Van der Brugghen 1993, Märss \& Ritchie 1998). Therefore it is not necessary to describe in more detail their discrete scales. They are relatively small nectobenthonic forms of fish.

The genus Helenolepis, studied on isolated material from Tuva (Karatajute-Talimaa 1978) is related to the genus Phlebolepis. According to their form and internal composition (presence of a secondary cavity inside of the basal plate), the Helenolepis navicularis scales are very diverse. They are oblong, narrow, with lengthwise sculpture and might belong to a more mobile animal.

Astraspids. The ontogenetic development of the tesserate armour of astraspids clearly has been explained by Tarlo (1967, fig. 2, Halstead 1987, fig. 2) (Fig. 13) using the dorsal side of $A s$ traspis desiderata Walcott as an example. The same figure shows three stages of tesserae formation; this is used as an example of cyclomorial growth of the dermal cover.

Denison (1967) distinguished several morphological varieties of tesserae, dorsal tesserae, dorsal ridge plates, marginal plates, ventral plates and scales, which have covered the posterior part of the body and tail area. A smooth overlying belt in the anterior part and elongated tubercles are peculiar to these scales.

Tesakoviaspis. Single primordial tubercles, tesserae with an incomplete first areal zone of growth, circular tesserae with one, or several areal growth zones and polygonal tesserae, have been found among Late Ordovician and Early Llandoverian material of the genus Tesakoviaspis from Siberia. Dorsal, marginal and ventral plates are not found. Single tubercles and tesserae with round, oval and elongate (drop-like) tubercles are found in the morphological set of $T$. concentrica (see Text-fig. 21). The first two varieties of tesserae occur, possibly, in the anterior part of the body, and tesserae with lengthwise tubercles in its posterior part. The orientation of the droplike tubercles is peculiar, the sharp end of all tubercles is directed backwards in such tesserae, so that the longitudinal lines of oblong tubercles, which presumably have a similar function as in sculptural elements for water flow regulation, were formed on the dermal cover.

The cyclomorial elements were enlarged by addition of new odontode-tubercles in areal zone of growth. The tesserae of astraspids, tesakoviaspids and, possibly, of tesserate heterostracans remaine stable in number during ontogeny, and are not shed. After the third growth stage, when the tesserae gained a polygonal form and are packed close to each other, thickening of the basal bone occurs - by addition of new laminae and by addition of additional generations of tubercles.

Acanthodians. Squamation of this group of fishes consists only of growing micromeric scales and tesserae and is not notable for its great topographic variation (Valiukevicius 1985, 1992, Heidtke 1990). The exoskeleton consists of a great number of plates, different in form and size only in the head area (particularly in climatiids). On reconstructions of the head exoskeleton of Climatius reticulatus AG. (Watson 1937, Novitskaya \& Obruchev 1964) and Brachyacanthus scutiger Egerton (Watson 1937, Denison 1979), the diversity of form and ornamentation of plate-tesserae, covered in odontodes or dentine tubercles (Gross 1971, Denison 1979: fig. 16), are represented.

Until recently, the squamation of most acanthodians species has been comparatively poorly studied. The most detailed knowledge of the squamation and its changes during growth can be found in Zidek (1985), devoted to the genus Acanthodes (also Heidtke 1990: fig. 52). Investigation of Acanthodes bridgei Zidek with intact specimens of different sizes, has indicated that the squamation does not develop simultaneously on the whole body, but it starts to appear only on its posterior part and along the main lateral line. Advancing in age, the squamation covers areas up to the pectoral fins and up to the head area from the ventral side and, partly, the head. However, such reduced squamation is peculiar to later, Carboniferous forms. The squamation of Silurian representatives of acanthodians is well developed and covers the whole body, including fins. These diamondshaped scales are sculptured by lengthwise ridges, or with partly smooth crown (Nostolepis, Cheiracanthoides, Gomphonchus). 
The squamation of Early Silurian acanthodians from Siberia, Tuva and Western Mongolia differs by its greater morphological variation (Karatajute-Talimaa et al. in prep.). In new Llandoverian genera (gen. nov. 1 and gen. nov. 2) the head (possibly, part of the body, too) is covered by scales with a smooth crown of areal growth. The body surface (trunk) is covered by diamondshaped transitional and body scales; the crowns grow areosuperpositionally or superpositionally, and longitudinal ridges develop on the crown surface.

The large material on discrete gen. nov. 2 scales allows compilation of a complete morphological set, the scales-tesserae of some morphological variants, possibly, could also be included in its composition. Placing scales-tesserae on the head area, the scales with smooth crown of areal growth could be disposed partly on head and partly behind it and, possibly, partly on the ventral body area, too.

Though the new Llandoverian acanthodian genera from Central Asia are represented only by scale material, nevertheless, they illustrate well new, earliest stages of acanthodian scales and development of the squamations. The areal crown growth of a large part of the scales, including in part diamond-shaped scales, undoubtedly, is an archaic feature. The "cephalic" scales with smooth crown, which were disposed densely and mosaic-like on the skin, making certain exoskeletal areas immobile, are extremely unusual. If we consider, that the basal plates of gen. nov. 2 scales have reached greatly impressive sizes, the front part of the body was well protected. Only the posterior part of the body and an area of the tail has been covered by mobile diamond-shaped scales, very characteristic of later acanthodians, judging by the quantitative ratio of head, transitional and body scales found in the samples.

Apparently, the number of scales has remained stable during the ontogenetic development of the acanthodian squamation. All the scales increased in size by addition of areal growth zones to the crown throughout ontogeny (Zidek 1985: 159).

Chondrichthyes. Highly valuable observations on the squamation and its changes during

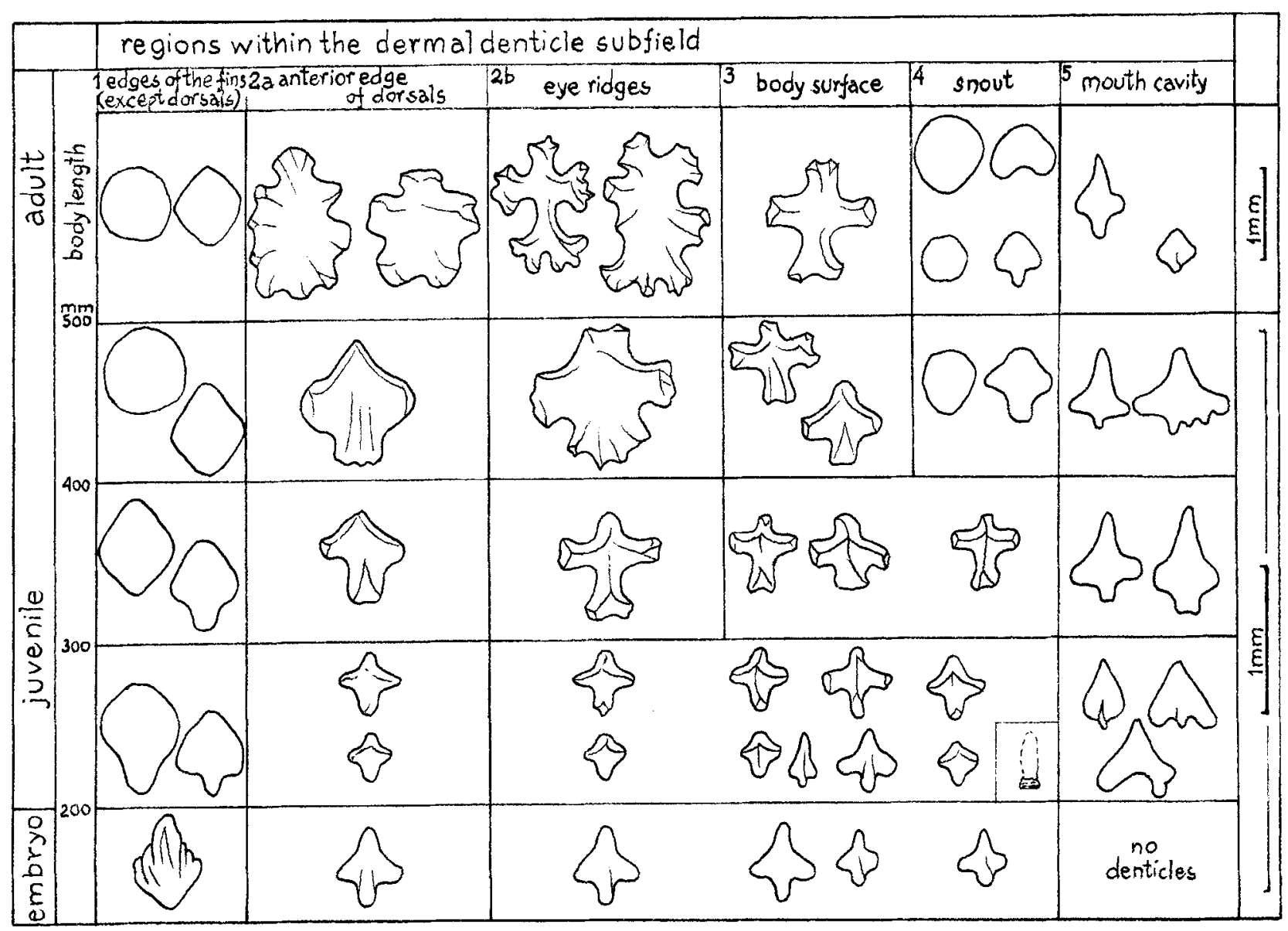

Fig. 23. Ontogeny of the dermal denticle subfield of Heterodontus galeatus (after Reif 1974, fig. 4) 
ontogeny of the Recent shark genus Heterodontus (Selachii), are given by Reif (1973b, 1974). He studied the squamation of embryo, juvenile and adult individuals and traced morphological changes of scales, which occur during growth in different regions of the body (Fig. 23). Not only does considerable increase in size of the scales occur, but also considerable complexity of crown forms was revealed. The number of dermal teeth (placoid scales) remains stable during ontogeny, because shedding scales is substituted by larger ones, and thus the growth of the body surface is compensated this way.

It is very important to note that crown scales which occur during growth of the fish on different parts of the body change in form (Reif 1974: fig. 4). Scale crowns of quite uniform form cover the skin of the embryo and early juvenile animals. Scales with a smooth crown on the snout area appear only in adult individuals, and scales with complex crowns develop gradually on the dorsal fins, around the eye area and body, beginning with late juvenile stage. Scales of larger individuals acquire rather complicated contours. It is interesting to note that scales with smooth crowns, of heterodont sharks, develop at the ends of the fins (except the dorsal fin) in individuals of all stages. The scales with a smooth crown, usually are considered as cephalic squamations of Palaeozoic vertebrate groups.

Approximately, the same changes in the squamation have been mentioned during studies of fossilized, intact specimens of Heterodontus falcifer from the lower Tithonian of Germany (Reif 1973b).

Reif (1978) created the new terms, growing and non-growing scales, and, chiefly, distinguished four morphogenetic types of elasmobranch exoskeleton. The investigations have been carried out on intact specimens of Ctenacanthidae from the Lower Carboniferous and Hybodontidae from the Middle Triassic and Lower Cretaceous, and on material of Euselachii from the Lower Jurassic and extant forms. Reif came to the conclusion that a great diversity of growth types are found in the squamation of $\mathrm{Pa}$ laeozoic chondrichthyans. During the Mesozoic and Cenozoic the last ctenacanthids, hybodontids and, particularly, euselachians exist. Their squamation develops comparatively identically.

The main problem, which has arisen before investigations of Palaeozoic elasmobranchs, mainly in "cladodontids", is as follows: Has the growth of scales lasted during the whole individual life or were they shed after some growth period? Reif has drawn his conclusions from Devonian and Early Carboniferous material, Protacrodus vetustus (Gross 1938) and Holmesella? sp. (Ørvig 1966). The scales in the squamation of same forms have approximately the same number of growth rings (plates) at the same size, which indicates regular, co-ordinated simultaneous growth of the exoskeleton. Apparently, primordia of each scale is laid down and later each passes through all stages of growth. The
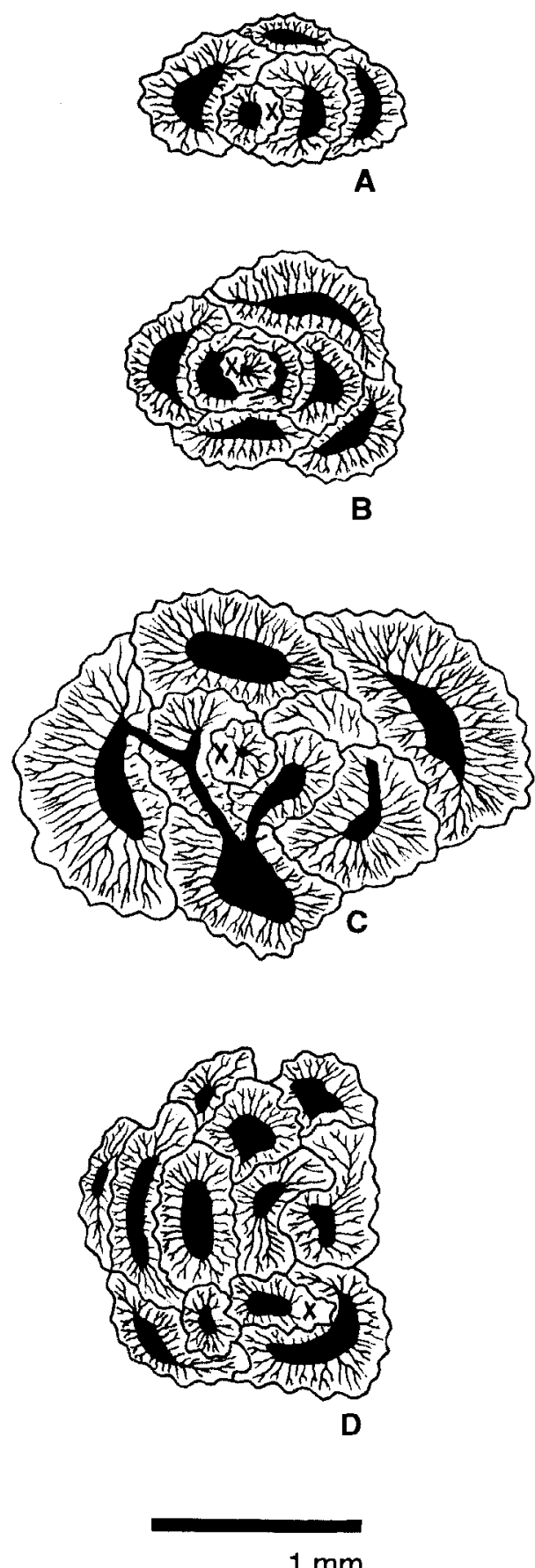

Fig. 24. A-D, Stiphronal cyclomorial scales of hybodontids from the Rhaetian. $\mathbf{x}$ - primordial tubercle (after Reif 1978 , fig.7, D, E, F, G) 
number of scales does not increase by insertion of new ones (Fig. 24).

Single odontodes and complex growing scales, also synchronomorial scales, are found in the squamation of hybodonts; the type of growth has been determined by Reif as transitional between growing and non-growing ones (Fig. 25). According to Reif, each fish has many growing scales, when they reach a certain size. Increase in the number of growing scales occurs together with increase of body surface, so that they are different from each other in the number of odontodes. Growth is irregular.

Reif (1978: 126, 127) distinguished three morphological types of scales and four morphogenetic types of squamation of elasmobranchs. The three morphological types are as follows: 1) Placoid type of scales, simple non-growing scales; 2) hybodontid type of scales, growing or non-growing squamation; 3) ctenacanthid type of scales, growing or non-growing scales. The four morphogenetic types of scales are as follows: 1. Type Heterodontus; 2. type Protacrodus; 3 . type Ctenacanthus costellatus; 4. type Hybodus delabechei.

In 1980 Reif determined already 17 theoretical types of morphogenesis of elasmobranch squamation. Four following parameters have been taken into account for their determination: rate of shedding, rate of scale growth, rate of in-
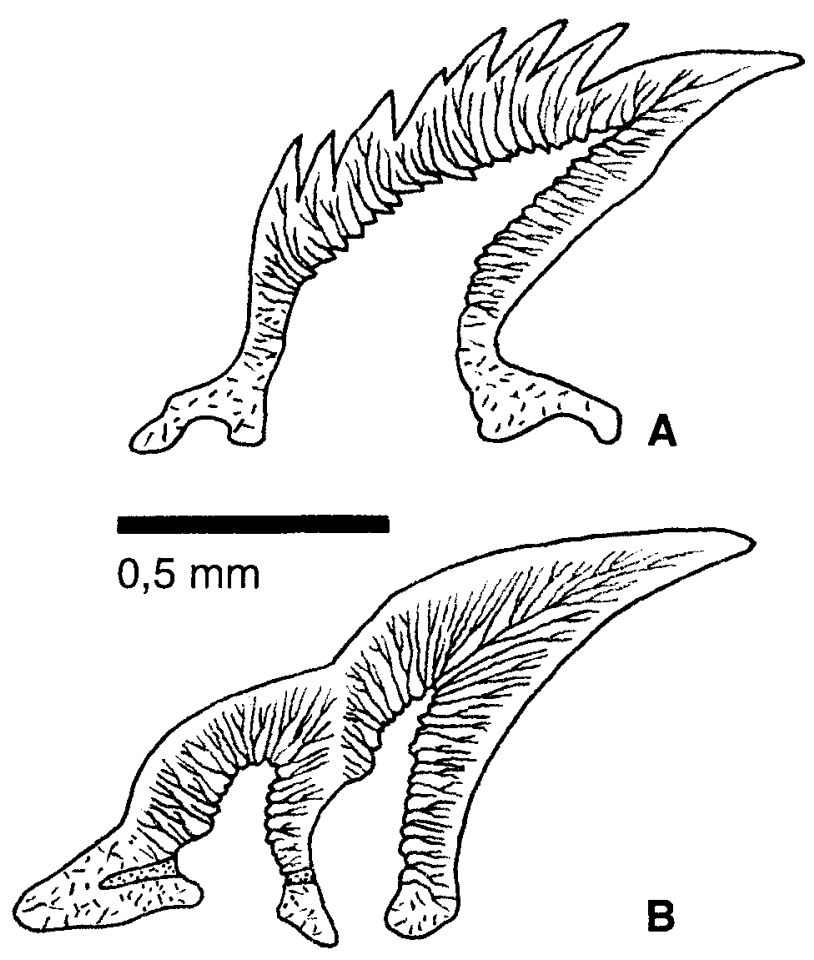

Fig. 25. Thin sections of Hybodus delabechei scales. A, single odontode, non growing; $\mathbf{B}$, intermediate situation between growing and non-growing scales (after Reif 1978, fig. 3 B, D) crease in size and rate of increase in number. The four morphogenetic types, distinguished by Reif in 1978, were included in this number. The remaining types have been distinguished in extant sharks, or calculated merely theoretically.

Reif's work "Squamation and ecology of sharks" (Reif 1985) is devoted to the study of the extant shark squamation. Information of comparative morphology of placoid scales, their histology is given and, above all, morphogenesis of the squamations of 29 shark families is discussed. Also the problem of taxonomic significance of placoid scales for Recent sharks is discussed. Reif (1985: 89) stated, that "It is doubtful whether isolated fossil placoid scales can be identified down to the genus or species". Such a pessimistic conclusion, which the author reached after many fundamental investigations, explains why, until now, the taxonomy of most fossilised elasmobranchs is based mainly on tooth studies, and very little attention has been paid to the study of discrete scales (with exception of Palaeozoic ones). However, Reif does not deny, that fossilised "form-species", determined on isolated scales, can be used for stratigraphical purposes.

However, the collections of isolated Early Palaeozoic chondrichthyans scales from Central Asia have proven, that it is possible to obtain a rather complete idea about the squamation and, consequently, about genus and species only on the basis of micromeric discrete material.

Karatajute-Talimaa (1992) has examined squamations of Palaeozoic Chondrichthyes. The morphogenetic types of dermal skeleton are as follows: Heterodontus, Elegestolepis, Ctenacanthus, Altholepis, Protacrodus, Seretolepis, Polymerolepis, Lugalepis and Mongolepis. They have been determined among Silurian and Devonian Chondrichthyes. Simple monodontodia, complex monodontodia and polyodontodia of different genesis were distinguished among scales of Palaeozoic Chondrichthyes.

The simple non-growing scales are peculiar to two morphogenetic types: Elegestolepis and Heterodontus.

1. Type Elegestolepis is the simplest type of squamation (Karatajute-Talimaa 1973). The scales with one pulp cavity, one neck and one basal canal are of shedding type. Substitution of them by larger ones occurs. Growth of the skin is compensated by increase in substitution and addition of new scales. The number of scales increases during ontogeny. Diversity 
of morphological scale types in squamation is slight.

2. Type Heterodontus: Scales of this dermal skeleton type do not grow at all. They shed and are substituted by new ones after some time. Growth of the skin is compensated by a gradual increase of size in the substitution and addition of new scales. The number of scales considerably increased during ontogeny. Different regions of squamation are characterized by scales of different morphology (Fig. 23).

The following examples of growing scales are characteristic of squamations of the following four morphogenetic types: Ctenacanthus (Hybodus), Altholepis, Protacrodus, Seretolepis.

1. Type Ctenacanthus: All scales grow by addition of new odontodes. However, their number does not remain stable during ontogeny, but increases by formation of new scales. The growth of skin is compensated by both growth of individual scales and insertion of new growing scales. The number of scales is increased during ontogeny.

2. Type Altholepis: Squamation consists of polyodontodia, growing scales (Karatajute-Talimaa; 1992, 1997c). The basal plate is slightly concave. Addition of odontodes on scales crowns occurs marginally and posterior to the primordial odontode. Growth is regular, scales are not shed, but apparently growth of the skin is compensated only by growth of individual scales.

3. Type Protacrodus: Squamation consists of polyodontodia, growing scales with convex basal plate. All scales grow by addition of new odontodes to the crown. The number of scales remains stable during ontogeny, and scales are not shed, nor are they fixed deeply in the skin.

4. Type Seretolepis: Squamation consists of polyodontodia of areal and semi-areal growth (Karatajute-Talimaa 1968, 1997c). The odontodia by their form are reminescent of odontode-like spherical plates of acanthodians. The basal plate is small and concave. Addition of odontodes does not occur regularly. Apparently, the squamation does not increase only by growth of scales, but by addition of new scales too.

Scales with non-growing crowns are characteristic of the remaining three morphogenetic types of squamations, Polymerolepis, Lugalepis and Mongolepis.
1. Type Polymerolepis: Squamation consists of complex monodontodia and polyodontodia of synchronomorial growth (KaratajuteTalimaa 1977). Like all non-growing scales, they are shed and have been substituted by larger ones. Growth of the skin is compensated both by larger sizes of substituted scales, and by addition of new scales. The general number of scales increases during ontogeny.

2. Type Lugalepis: Squamation consists of polyodontodia, where all odontodes form simultaneously (Karatajute-Talimaa 1997a). The basal plate of scales is thin, slightly concave. Scales are shed and replaced. Growth of the skin is compensated by larger size of substituted scales and apparently by addition of scales in new positions.

3. Type Mongolepis: Squamation consists of polyodontodia, where odontodes form synchronously in longitudinal rows, the original "odontocomplexes". The crown is of nongrowing type, and the basal plate is convex and growing. Scales are shed and substituted by larger ones. Growth of the skin is compensated, mainly, by larger size of substituted scales. Formation of inserted new scales is possible.

During the last decades, much attention has been devoted to the characteristics of tissue types of exoskeleton of vertebrates, their histogenesis or skeletogenesis in the following works: Ørvig (many papers), Halstead (1987), Maisey (1988), Smith \& Hall (1990, 1993), Smith (1995) and others. This is a particularly important part in any investigation of vertebrate exoskeletons, and thus, in this article brief information on some varieties of dentine tissues is presented.

The investigations of morphology, histology and type of growth of exoskeletal elements of most ancient vertebrates, undoubtedly, will lead to new interesting discoveries. New material from the Upper Ordovician and Lower Silurian of Timan-Pechora Region and Central Asia (South Siberia, Tuva, West Mongolia) considerably expands our knowledge on proposed phylogenetic stages of main types of exoskeleton tissues. The following three new varieties have been found among dentinoidal tissues: atubular dentine, lamelline (Karatajute-Talimaa et al. 1990; Karatajute-Talimaa \& Novitskaya 1992, 1997; Karatajute-Talimaa 1995), mesodentine, consisting of particularly thin canals (Karatajute-Talimaa 1997b) and archaic mesodentine, very little 
different from bony tissue, formed by common bone cells (Karatajute-Talimaa et al. in prep.).

In my opinion, lamelline which is found not only in odontodes of Mongolepidida scales, in the crown of Tesakoviaspis tesserae, but also in the crown of some odontod from the Harding Sandstone, too (Märss, pers. comm.), is of great interest. The thin-laminated tissue is found also in the upper layer of the dermal armour of the supposed Late Cambrian vertebrate from Australia (Young et al. 1996). Apparently, the lamelline or the atubular dentinoidal tissue, like lamelline, has been developed in the exoskeleton of many most ancient vertebrates. The tissues of such a type may be compared with lamellar hyaline hard tissue, developed in the crown of euconodonts (see the discussion in the article Schultze 1996). It is necessary to conduct research of lamelline and tissues like lamelline at ultrastructural level in confirmation of such a supposition.

\section{Conclusions}

Discrete skeletal elements (scales and tesserae) of early vertebrates belonging to different groups may be successfully ascribed to species and genus (also taxonomic units of higher rank). It is desirable along this to observe the distinct methodic requirements.

For determination of species and genus it is necessary to use material collected from single or several samples from the same bed. Compilation of morphological sets, reflecting limits of variable shapes of scales or tesserae for each species, formes a true notion on individual squamation, nearing themselves an artificial classifications to natural systematic. For identifications to which genus they belong, investigations have to include the inner composition (tissue types) of all skeletal elements of different morphological varieties and determine the growth type as well. More complete material gives a possibility to trace an ontogenetic development sequence of dermal skeletal elements.

Following the examples of such Palaeozoic groups of early vertebrates as thelodonts, astraspids, Tesakoviaspis, acanthodians and chondrichthyans, are researched possible variations of squamation, composed by micromeric scales and tesserae.

I have the hope, this article will help to a certain extent in classification of micromaterial and determination of its taxonomical affiliation.

\section{Acknowledgements}

An early version of the manuscript was reviewed by Dr. Susan Turner. Her helpful written comments have been incorporated in the text and are gratefully acknowledged. I am grateful to Dr. Moya Smith for critically reviewing the manuscript, for helpful discussions and correcting of the English. I thank Prof. Dr. Hans-Peter Schultze for providing editorial comments.

\section{References}

Denison, R. H. 1967. Ordovician vertebrates from western United States. - Fieldiana-Geology 16: 131-192.

- 1979. Acanthodii. In Schultze, H.-P. (ed.) Handbook of Paleoichthyology, 5: 62 pp., Gustav Fischher Verlag, Stuttgart-New York.

Doyle, P. S. \& Riedel, W. R. 1979. Ichthyoliths: Present status of taxonomy and stratigraphy of microscopic fish skeletal debris. - Scripps Institution of Oceanography Reference Series 16: 231.

Gross, W. 1938. Das Kopfskelett von Cladodus wildungensis JAEKel. 2. Teil: Der Kieferbogen. Anhang: Protacrodus vetustus JAEKEL. - Senkenbergiana 20: 123-145.

- 1947. Die Agnathen und Acanthodier des obersilurischen Beyrichienkalks. - Palaeontographica A 96: 91-158.

- 1966. Kleine Schuppenkunde. - Neues Jahrbuch für Geologie und Paläontologie, Abhandlungen 125: 29-48.

- 1967. Über Thelodontier-Schuppen. - Palaeontographica A 127: $1-67$.

- 1968. Porenschuppen und Sinneslinien des Thelodontiers Phlebolepis elegans PANDER. - Paläontologische Zeitschrift 42: 31-146.

- 1971. Downtonische und dittonische Acanthodier-Reste des Ostseegebietes. - Palaeontographica A 136: 82.

- 1973. Kleinschuppen, Flossenstacheln und Zähne von Fischen aus europäischen und nordamerikanischen Bonebeds des Devons. - Palaeontographica A 142: 51-155.

Halstead, L. B. 1987. Evolutionary aspects of neural crestderived skeletogenic cells in the earliest vertebrates. In Maderson, P. F. (ed.), Developmental and Evolutionary Aspects of the Neural Crest: 339-350, John Wiley Sons, New York.

Heidtke, U. 1990. Studium über Acanthodes (Pisces: Acanthodii) aus dem saarpfälzischen Rotliegend (?Ober-Karbon-Unter-Perm, SW-Deutschland). - Pollichia 19: $1-86$.

Hertwig, O. 1874. Ueber Bau und Entwicklung der Placoidschuppen und der Zähne der Selachier. - Jenaische Zeitschrift Naturwissenschaft 8: $331-404$.

- 1876. Ueber das Hautskelet der Fische. - Morphologisches Jahrbuch 2: 1-68.

- 1879. Ueber das Hautskelet der Fische. II. Das Hautskelet der Ganoiden (Lepidosteus und Polypterus). - Morphologisches Jahrbuch 5: 69-89.

Janvier, P. 1996. Early vertebrates. - Oxford Monographs on Geology and Geophysics. 364 pp., Clarendon Press, Oxford.

Karatajute-Talimaa, V.N. 1968. [New thelodonts, heterostracans and arthrodires from the Chortkov Stage of Podolia]. In Obruchev D.V. (ed.). Sketches in phylogenesis and taxonomy of fossil fishes and Agnatha: 33-42. Moscow "Nauka". [In Russian].

- 1973. Elegestolepis grossi gen. et sp. nov., ein neuer Typ der Placoidschuppe aus dem oberen Silur der Tuwa. Palaeontographica A 143: 35-50.

- 1977. [Structure and systematic position of scales of Polymerolepis whitei Karatajute-Talimaa]. In Menner V.V. (ed.). Sketches on phylogenesis and taxonomy of fossil fishes and Agnatha: 46-60 Moscow "Nauka" [In Russian]. 
- 1978. [Silurian and Devonian thelodonts of the USSR and Spitsbergen]: 334 pp., "Mokslas", Vilnius [In Russian].

- 1992. The early stages of dermal skeleton formation in chondrichthyans. In Mark-Kurik, E. (ed.) "Fossil fishes as living animals", Academia Nr.1: 223-231, Tallinn.

- 1995. The Mongolepidida: scale structure and systematic position. - Geobios, Memoire special 19: 35-37.

- 1997a. Lugalepis - new genus of elasmobranchs from Devonian of western part of the Main Devonian Field. Geologija 21: 24-31, Vilnius.

- 1997b. Taxonomy of loganiid thelodonts. - Modern Geology 21 (1/2): 1-16.

- 1997c. Chondrichthyan scales from Lochkovian (Lower Devonian) of Podolia (Ukraine). - Geologija 22: 5-17, Vilnius.

Karatajute-Talimaa, V. N., Novitskaya, L. I., Rozman, K. S. \& Sodov, J. 1990. [Mongolepis - a new Lower Silurian elasmobranch genus from Mongolia]. - Paleontological Journal 1: 76-86 [In Russian].

Karatajute-Talimaa, V. N. \& Novitskaya, L. I. 1992. [Teslepis - a new genus of mongolepid elasmobranch from the Lower Silurian of Mongolia]. - Paleontological Journal 4 36-46 [In Russian].

- 1997. [Sodolepis, a new representative of the Mongolepidida (Chondrichthyes?) from the Lower Silurian of Mongolia]. - Paleontological Journal 5: 96-103 [In Russian].

Karatajute-Talimaa, V. \& Predtechenskyj, N. 1995. The distribution of the vertebrates in the Late Ordovician and Early Silurian palaeobasins of the Siberian Platform. - Bulletin du Museum national d'Histoire naturelle, Paris, $4 \mathrm{e}$ serie, 17, Section C, Nr. 1-4: 39-55.

Karatajute-Talimaa, V., Smith, M. M. \& Turner, S. (in prep.). New acanthodians from the Lower Silurian deposits of Siberian Platform. - Palaeontology.

Maisey, J. G. 1988. Phylogeny of Early Vertebrate skeletal induction and ossification patterns. In Hecht, M.K., Wallace, B. \& Prance, G.T. (eds.). - Evolutionary Biology 22: $1-36$.

Märss, T. 1986a. Silurian vertebrates of Estonia and West Latvia. - Fossilia Baltica: 104 pp., "Valgus", Tallinn [In Russian, English abstract].

- 1986b. Squamation on the thelodont agnathan Phlebolepis. - Journal of Vertebrate Paleontology 6 (1): 1-11.

Märss, T. \& Ritchie, A. 1998. Articulated thelodonts (Agnatha) of Scotland. - Transaction of the Royal Society of Edinburgh, Earth Sciences 88: 143-195.

Moskalenko, T. A. 1968. [The Llandoverian remains of Agnatha in Siberia]. In Obruchev, D. V. (ed.). Sketches in phylogenesis and taxonomy of fossil fishes and Agnatha: 29-31, "Nauka", Moscow [In Russian].

Moss, M. L. 1970. Enamel and bone in shark teeth. - Acta Anatomica 77: $161-187$.

Novitskaya, L. I. \& Karatajute-Talimaa, V. N. 1986: [Remarks about the cladistic analysis in connection with myopterygian hypothesis and the problem of the origin of gnathostomes]. In Vorobyeva, E. \& Lebedkina, N. (eds.) "Morphology and evolution of animals": 102-125, "Nauka", Moskow [In Russian].

Novitskaya, L. \& Obruchev, D. V. 1964. Class Acanthodei. In Obruchev, D. V. (ed.), Osnovy Paleontologii, 11. Agnatha and Pisces: 175-194, "Nauka", Moscow [In Russian].

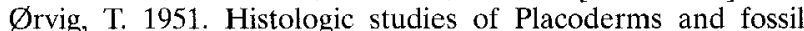
Elasmobranchs. 1. The endoskeleton with remarks on the hard tissues of lower vertebrates in general. - Arkiv för zoologi 2 (2): 321-454.

- 1966. Histologic studies of ostracoderms, placoderms and fossil elasmobranchs. 2. On the dermal skeleton of two Palaeozoic elasmobranchs. - Arkiv för zoologi 19 (1): $1-39$.

- 1967. Phylogeny of tooth tissues: Evolution of some calcified tissues in early vertebrates. $n$ Miles, A. E. W. (ed.). Structural and Chemical Organization of Teeth 1: 45-110, Academic Press, New York.
1968. The dermal skeleton, general considerations. In Ørvig (ed.). Current Problems of Vertebrate Phylogeny, Nobel Symposium 4: 373-397, Stockholm, Almquist Wiksell, Stockholm.

- 1977. A survey of odontodes ("dermal teeth") from developmental, structural, functional and phyletic points of view. In Andrews, S. M, Miles, R. S. \& Walker, A. D. (eds.). Problems in Vertebrate Evolution. Linnean Society Symposium Series 4: 53-75.

Reif, W.-E. 1973a. Morphologie und Ultrastruktur des Hai"Schmelzes". - Zoologica Scripta 2: 231-250.

- 1973b. Ontogenese des Hautskelettes von Heterodontus falcifer (Selachii) aus dem Untertithon. Vergleichende Morphologie der Hautzähnchen der Haic. - Stuttgarter Beiträge zur Naturkunde 7: 1-16, Stuttgart.

- 1974. Morphogenese und Musterbildung im Hautzähnchen-Skelett von Heterodontus. - Lethaia 7: 25-42.

- 1978. Types of morphogenesis of the dermal skeleton in fossil sharks. - Paläontologische Zeitschrift 52: 110-128.

- 1980. A model of morphogenetic processes in the dermal skeleton of elasmobranchs. - Neues Jahrbuch für Geologie und Paläontologie, Abhandlungen 159: 339-359.

- 1982a. Evolution of the dermal skeleton in vertebrates: The Odontode - Regulation Theory. - Neues Jahrbuch für Geologie und Paläontologie, Abhandlungen 164: $139-142$.

- 1982b. Evolution of the Dermal Skeleton in Vertebrates: The Odontode - Regulation Theory. - Evolutionary Biology 15: $287-368$.

- 1985. Squamation and ecology of sharks. -- Courier Forschungsinstitut Senckenberg 78: 1-255.

Schaeffer, B. 1977. The dermal skeleton in fishes. In Andrews, S. M., Miles, R. S. \& Walker, A. D. (eds.). Problems in Vertebrate Evolution. Linnean Society Symposium Series 4: 25-52.

Schultze, H.-P. 1996. Conodont histology: an indicator of vertebrate relationship? - Modern Geology 20: 275-285.

Smith, M. M. 1995. Heterochrony in the evolution of enamel in vertebrates. In McNamara, K. J. (ed.). Evolutionary Change and Heterochrony: 125-150, John Wiley Sons, New York.

Smith, M. M. \& Hall, B. K. 1990. Developmental and evolutionary origins of vertebrate skeletogenic and odontogenic tissues. - Biological Reviews 65: 277-374.

1993. A developmental model for evolution of the vertebrate exoskeleton and teeth: the role of cranial and trunk neural crest. - Evolutionary Biology 27: 387-447.

Stensiö, E. A:son. 1961. Permian vertebrates. In Raasch, G.O (ed.). Geology of the Arctic: 231-247, Toronto.

- Origine et nature des ecailles placoides et des dents. Colloques Internationaux du Centre National de la Recherche Scientifique 104: 75-85.

- 1964. Les cyclostomes fossiles on ostracodermes. In Piveteau, J. (ed.). Traite de Paleontologie 4 (1): 96-382, Paris.

Stensiö, E. A:son. \& Ørvig, T. 1951. On the scales of elasmobranchs. (Manuscript).

Talimaa, V. N. \& Melnikov, S. V. 1987. [Significance of vertebrates for basement of unified and correlative schemes of Devonian system of Timan-Pechora subregion]. In Kaljo, D. L. (ed.). Decisions of interdepartmental stratigraphical meeting on Ordovician and Silurian systems of East-European platform in 1984 with regional stratigraphical schemes: 13-16. "Nedra", Leningrad [In Russian].

Tarlo, L. B. H. 1967. The tessellated pattern of dermal armour in the Heterostraci. - Journal of the Linnean Society (Zoology) 47: 45-54.

Turner, S. 1976. Thelodonti (Agnatha). In Westphal, F. (ed.). Fossilium Catalogus I: Animalia, Pars 122: 1-35.

- 1982. A new articulated thelodont (Agnatha) from the Early Devonian of Britain. - Palaeontology 25: 879-889.

1984. Studies on Palaeozoic Thelodonti (Craniate: Agnatha). - Unpub. Ph.D. Thesis, University Newcastleupon-Tyne. 
- 1986. Thelodus macintoshi STETSON 1928, the largest known thelodont (Agnatha: Thelodonti). - Breviora 486: $1-18$.

- 1991. Monophyly and interrelationship of the Thelodonti. In Chang Mee-Mann, Liu Yu-Hai \& Zang Guo-Rui (eds.). Early Vertebrates and related problems of evolutionary biology: 87-119. Science Press, Beijing.

- 1992. Thelodont life styles. In Mark-Kurik, E. (ed.). "Fossil fishes as living animals", Academia, Nr. 1: 21-40, Tallinn.

Turner, S. \& Van der Brugghen, W. 1993. The Thelodonti, an important but enigmatic group of Palaeozoic fishes. Modern Geology 18: 125-140.

Turner, S. \& Nowlan, G. S. 1995. Early Silurian microvertebrates of Eastern Canada. - Bulletin du Museum national d'Histoire naturelle, Paris, $4 \mathrm{e}$ serie, 17, Section C. Nr.1-4: 513-529.

Tway, L. E. 1979. A coded system for utilizing ichthyoliths of any age. - Micropalaeontology 22 (2): 129-142.

- 1984. A coded utilitarian system for identifying Palaeozoic ichthyoliths. - Journal of Vertebrate Palaeontology 3 (4): 187-199.

Tway, L. E. \& Zidek, J. 1982. Catalog of Late Pennsylvanian ichthyoliths, part I. - Journal of Vertebrate Palaeontology 2 (3): $328-361$.
- 1983a. Catalog of Late Pennsylvanian ichthyoliths, part II. - Journal of Vertebrate Palacontology 2 (4): 414-438.

- 1983b. Catalog of Late Pennsylvanian ichthyoliths, addendum. - Journal of Vertebrate Palaeontology 3(2): $67-68$.

Valiukevicius, J. J. 1985. [Acanthodians from the Narva Regional Stage of the Main Devonian Field]. 144 pp., "Mokslas", Vilnius [In Russian].

- 1992. First articulated Poracanthodes from the Lower Devonian of Severnaya Zemlya. In Mark-Kurik, E. (ed.). "Fossil fishes as living animals", Academia. Nr. 1: 193-213, Tallinn.

Watson, D. M. S. 1937. The acanthodian fishes. - Philosophical Transactions of the Royal Society London 228: $49-146$.

Young, G. C., Karatajute-Talimaa, V. N. \& Smith, M. M. 1996. A possible Late Cambrian vertebrate from Australia. - Nature 383: 810-812.

Zangerl, R. 1981. Chondrichthyes I. Palaeozoic Elasmobranchii. In Schultze, H.-P. (ed.). Handbook of Paleoichthyology, 3A, 115 p. Gustav Fischer Verlag, Stuttgart-New York.

Zidek, J. 1985. Growth in Acanthodes (Acanthodii: Pisces) data and implications. - Paläontologische Zeitschrift 59: $147-166$. 